\title{
The Mohorovičić Discontinuity Beneath the Continental Crust: An Overview of Seismic Constraints
}

\author{
Ramon Carbonell ${ }^{\mathrm{a}, \mathrm{b}}$, Alan Levander ${ }^{\mathrm{c}}$, Rainer Kind ${ }^{\mathrm{d}}$ \\ ${ }^{a}$ Earthquake Research Institute, Tokyo University, Tokyo, Japan \\ ${ }^{b}$ CSIC-Inst. Ciències de la Terra Jaume Almera, Barcelona, Spain \\ ${ }^{c}$ Rice Univ. Houston, TX, USA \\ ${ }^{d}$ GFZ, Potsdam, Germany
}

\begin{abstract}
The seismic signature of the Moho from which geologic and tectonic evolution hypothesis are derived are to a large degree a result of the seismic methodology which has been used to obtain the image. Seismic data of different types, passive source (earthquake) broad-band recordings, and controlled source seismic refraction, densely recorded wide-angle deep seismic reflection, and normal incidence reflection (using VibroseisTM, explosives, or airguns), have contributed to the description of the Moho as a relatively complex transition zone. Of critical importance for the quality and resolution of the seismic image are the acquisition parameters, used in the imaging experiments. A variety of signatures have been obtained for the Moho at different scales generally dependent upon bandwidth of the seismic source. This variety prevents the development of a single universally applicable interpretation. In this way source frequency content, and source and sensor spacing determine the vertical and lateral resolution of the images, respectively. In most cases the different seismic probes provide complementary data that gives a fuller picture of the physical structure of the Moho, and its relationship to a petrologic crust-mantle transition. In regional seismic studies carried out using passive source recordings the Moho is a relatively well defined structure with marked lateral continuity. The characteristics of this boundary change depending on the geology and tectonic evolution of the targeted area. Refraction and wide-angle studies suggest the Moho to be often a relatively sharp velocity contrast, whereas the Moho in coincident high-quality seismic reflection images is often seen as the abrupt downward decrease in seismic reflectivity. The origin of the Moho and its relation to the
\end{abstract}


crust mantle boundary is probably better constrained by careful analysis of its internal details, which can be complex and geographically varied. Unlike the oceanic Moho which is formed in a relatively simple, well understood process, the continental Moho can be subject to an extensive variety of tectonic processes, making overarching conclusions about the continental Moho are difficult. Speaking very broadly: 1) In orogenic belts still undergoing compression and active continental volcanic arcs, the Moho evolves with the mountain belt, 2) In collapsed Phanerozoic orogenic belts the Moho under the collapse structure was formed during the collapse, often by a combination of processes. 3) In regions having experienced widespread basaltic volcanism, the Moho can result from underplated basalt and basaltic residuum. In Precambrian terranes the Moho may be as ancient as formation of the crust, in others Precambrian tectonic and magmatic processes have reset it. We note that seismic reflection data in Phanerosoic orogens as well as from Precambrian cratonic terranes often show thrust type structures extending as deep as the Moho, and suggest that even where crust and mantle xenoliths provide similar age of formation dates, the crust may be semi-allochothonous.

Keywords: Mohorovičić, Seismology, Seismic Reflection, Seismic

Refraction, Wide-angle reflection, Receiver function, Continental Crust

\section{Introduction: The Mohorovičić Discontinuity}

The discovery by Andrija Mohorovičić (1857-1936) in 1909 (Mohorovičićic 1910) of the seismic discontinuity that bears his name was among the first direct evidence of seismic velocity (and presumably density) layering in the Earth. The Moho's discovery was roughly contemporaneous with the seismic discovery of the core-mantle boundary by R.D. Oldham in 1908. Both the Moho and core-mantle boundary had been anticipated by scientists in 19th century from surface observations, and the latter had been inferred from the Earth's moment of inertia. The Moho defines the bottom limit of the crust, a differentiate of the mantle, separating the mantle, which forms $99 \%$ of the silicate Earth, from the chemically heterogeneous veneer of low density rocks comprising the crust. This structure constitutes a key element in understanding the physics behind the dynamic processes acting in the Earth's interior. It is generally the most important boundary in theories of isostasy and orogenesis. The volume of crustal rocks, as well as their chemistry, plays an important role in constraining models of early Earth evolution. The seis- 
mic work carried out since the Moho's discovery has been able to constrain the depth of this feature in most of the tectonic and geological terranes regardless of age, making the Moho an ubiquitous, global feature. The volume of crustal rocks, as well as their chemistry, plays an important role in constraining models of early Earth evolution. The seismic its discovery maps of the Moho topography at local, continental and even worldwide-scales have been estimated by interpolation (Mooney et al. 1998; Tesauro et al. 2008; Díaz and Gallart 2009; Grad and Tiira 2009; Salmon et al. 2012; Levander and Miller 2012).

The location, geometry and detailed structure of the Moho have been investigated by passive and controlled source seismic methods (Oliver 1982). Controlled-source refraction/wide-angle reflection surveys measure the propagation of head and diving waves and reflections with greater detail than is available from most earthquake studies, and have mapped the Moho in a long list of areas around the world. These have constrained the geometry of the transition from the crust above to the mantle below (see Prodehl and Mooney (2012) for a detailed overview).

The internal structure of the crust-mantle transition, its geometry and its fabric are characteristics that provide constraints on the processes acting in the upper mantle and at the base of the crust. These are key issues to understand the dynamics of tectonic processes, e.g. extension and collision, and their accompanying geochemical modifications and mass transfer. The detail structure of the Moho provides insight into mass transfer processes affecting crustal growth and accretion, underplating, and delamination (Hale and Thompson 1982; Larkin et al. 1996; Balling 2000; Morozov et al. 2001; Levander et al. 2011).

During the last few decades a large number of seismic reflection profiling programs in different parts of the world have provided thousands of kilometres of high resolution images of the crust and specifics of the crust-mantle transition. Such crustal images are unique clues for the interpretation of how regional tectonic features and structures observed at the Earth's surface are related to structures at depth, and may be explained in terms of crustforming tectonic processes (Mooney and Meissner 1992; Abbott et al. 1997; Cook et al. 2010).

The Moho has been largely defined on the basis of geophysical data, in particular potential field techniques, controlled source seismic profiling (Meissner 1973; Jarchow and Thompson 1989; Cook 2002; Eaton 2006; Cook et al. 2010; Oueity and Clowes 2010), and the analysis of passive source 
recordings. For example: teleseismic receiver functions (Langston 1979) which have been useful for estimating crustal thicknesses (and VP/VS ratios) beneath individual seismic stations (Zandt and Ammon 1995; Chevrot and van der Hilst 2000; Zhu and Kanamori 2000).

The knowledge obtained of this singular structure is dependent on the methodology used to obtain its image and the specific properties and resolution capabilities of the imaging techniques used. In the case of seismic

techniques, the images obtained are dependent on the frequency content of the source, on the angles of illumination of the structure, the geometry of the recording array and density of sensors that record the transmitted and scattered energy and the density of sources that illuminate it. These acquisition parameters control the resolution of the images of the Moho's structure.

Through the literature [published bibliography] it is easy to find the Moho discontinuity being qualified by adjectives that relate to the technique or data used to visualize or characterize it. For example the literature is replete with such phrases as the seismic Moho, the refraction Moho, the reflection Moho, the electric Moho (Jones and Ferguson 2001), the petrologic Moho (Jarchow and Thompson 1989) the gravity Moho (Holliger and Kemperer 1989). These reflect researchers attempts to develop a multidisciplinary view of this important structure integrating remote sensing interpretations with the geologic and petrologic data obtained from direct measurements on xenoliths or from the limited exhumed exposures of the crust-mantle transition. These data can be placed in a temperature depth context and provide a way to map crust-mantle stratigraphy in terms of rock types and fluid related processes (O'Reilly et al. 1994). Therefore, it is important to recognize that the knowledge obtained on the crust-mantle transition strongly depends on the remote sensing techniques which have been used and on their intrinsic resolution capabilities.

\section{Refraction and/or Wide-Angle Seismic Reflection}

Seismic profiling on a crustal scale has had a long tradition and has resulted in outstanding results. A very extensive compilation can be found in Prodehl and Mooney (2012). The acoustic energy produced by controlled explosions is recorded at distances from offsets of 0 to a few 100's or even 1000's of kilometres The resulting shot records are used to determine the velocity structure of the crust and upper mantle, this is known as the seismic refraction method. The seismic data are analyzed using modern computa- 
tional methods which permit $2 \mathrm{D}$ and $3 \mathrm{D}$ variations in velocities (Zelt and Smith 1992; Hole 1992; Hole and Zelt 1995; Zelt et al. 1996) but overall the analysis is similar to that done by Mohorovičić (Fig. 1).

Conventional seismic refraction data, which typically have sensor spacing of one to multiple kilometers, retrieve a simple step-like or a linear velocity gradient for the Moho discontinuity, with velocities that increase stepwise, or more gradually from $\mathrm{Vp}$ of 6.5 to $7.1 \mathrm{~km} / \mathrm{s}$ to $\mathrm{Vp}^{\prime}$ s greater than $7.6 \mathrm{~km} / \mathrm{s}$ to $8.0 \mathrm{~km} / \mathrm{s}$ (Fig. 1). This velocity jump has been interpreted as the transition from intermediate to mafic rocks of the lower crust to predominately ultramafic rocks typical of the upper mantle (Jarchow and Thompson 1989; Mooney and Meissner 1992; Christensen and Mooney 1995; Giese 2005). This velocity change happens at depth between 20 to $70 \mathrm{~km}$ in the Continental crust (Mooney et al. 1998; Tesauro et al. 2008; Díaz and Gallart 2009; Grad and Tiira 2009; Salmon et al. 2012). Almost a reflection of the Earths hypsographic profile, the histogram of global Moho depths clusters around two peaks, one characteristic of the continents and another the oceans. The continental depths are typically between 30 to $55 \mathrm{~km}$ for the former, with an average of $40 \mathrm{~km}$, and about $10 \mathrm{~km}$ for the oceans. (Mooney et al. 1998). Beneath continents there are local exceptions. There are large variations in both the magnitude of the velocity contrast and the vertical dimension over which it occurs within continental regions where an array of geological processes has affected the Moho, often episodically, over geological time. In an effort to provide a globally consistent definition, Steinhart (1967) proposed that the refraction Moho be the depth at which the P-wave velocity first increases rapidly or discontinuously to values above $7.6-8.6 \mathrm{~km} / \mathrm{s}$. If steep velocity gradients are not present, then the refraction Moho is interpreted as the level at which the P-wave velocity exceeds $7.6 \mathrm{~km} / \mathrm{s}$ (Steinhart 1967; Jarchow and Thompson 1989). This has been adopted as the definition by the geophysical community ensuring that a refraction Moho will be found everywhere around the world, but complicating its interpretation as the crust-mantle boundary.

In refraction seismology, the phase reflected at the Moho interface is labelled traditionally as $\mathrm{PmP}$ in the case of the reflected $\mathrm{P}$ wave and, $\mathrm{SmS}$ in the case of the reflected $\mathrm{S}$ wave (in a similar way the converted waves at the Moho are the PmS and SmP, for P-to-S and S-to-P conversions, respectively). The Pn phase is considered to be the head-wave bottoming within the upper mantle, just bellow the Moho discontinuity. A more general definition by IASPEI states that it is any $\mathrm{P}$ wave bottoming beneath the Moho and 
within the upper mantle not deeper than the base of the asthenosphere. This two phases where the key in Mohorovičić interpretation of the Earthquake recordings (Fig. 1).

Conventional refraction data acquisition relied on the observation of refracted phases over great enough distances to accurately measure phase velocity and reflected phases at distances that correspond to angles of incidence at and beyond the critical angle of refraction at the Moho to benefit from the high reflection coefficients (approaching 1), (Aki and Richards 1980). Therefore, in this type of data acquisition experiments it is important to cover relatively large offsets, often on the order of 200 to $300 \mathrm{~km}$, depending on crustal thickness, (Fig. 2). With the development of increasingly inexpensive, lightweight portable instrumentation, spatial density of the surface sensors has increased to multiple sensors $/ \mathrm{km}$ and the images of the Moho have improved as pre-critical incidence reflections are observable, where reflection coefficients are on the order of 0.1 and the shorter paths lead to much less energy being lost to attenuation. The decrease in station spacing increases the lateral continuity of the PmP phase as well as reveals more vertical detail in the pre-critical region. Vertical resolution is a fraction of vertical wavelength of the incident wavefield, which increases from $\lambda$ at normal incidence to $(\lambda / \cos \theta)$ at angle $\theta$. Since $\lambda \sim 1 / f$ increasing source frequency content can increase vertical resolution. The variation with offset of the amplitude of the PmP reflection and the increase in lateral resolution is demonstrated in Fig. 2. The increase in spatial density of the surface sensors revealed relatively strong spatial variability in the shape of the PmP arrival suggesting that the interpreted structure was more complex than a simple step or linear velocity gradient. Modern wide-angle studies have notably increased the number of instruments employed in an experiment, in the process revealing that the Moho discontinuity can exhibit considerable lateral and vertical variation (Fig. 2).

With the improvements in acquisition it has been evidenced that the characteristics of the Mohorovičić discontinuity have a strong dependence on the acquisition parameters: amplitude and frequency content of the source signal, the geometry and deployment parameters of the recording system (trace spacing, sampling interval, etc). Mainly the images have a high dependence on the dynamic characteristics of the source signal (Fig. 3). An example of the dependence of the variations of the $\mathrm{PmP}$ phase as a function of frequency content can be observed in the Refraction data acquired across the Ural Mountains (see fig 4 and 5 in Carbonell et al. (2000)). Another 
recent example revealing the $\mathrm{PmP}$ seismic signature variations with respect to frequency content is the wide-angle seismic reflection data acquired in the IBERSEIS research project in southwestern Iberia Peninsula (Fig. 3). In this case the seismic signature features a very noticeable change. The PmP at wide-angles (over $90 \mathrm{~km}$ offset) is observed in all the filter panels, while at offset distances $<50 \mathrm{~km}$ the seismic signature of the lower crust and Moho are only visible at higher frequencies (fig. 3). This latter effect is likely due to low frequency scattered surface waves from near surface irregularities Levander and Hill (1985).

Synthetic seismic modeling has demonstrated the importance of the scale/ dimensions of the heterogeneities within the lower crust and upper mantle and its relation with the wave-length of the illuminating seismic signal (Holliger and Levander 1992; Holliger et al. 1992; Levander and Holliger 1992; Holliger et al. 1993; Tittgemeyer et al. 1996, 1999; Ryberg et al. 2000). This has been more important as the acquisition technology has improved. As the acquisition parameters have changed (increasing the number of stations, the maximum offsets, the frequency content of the source signal and, decreasing the station spacing) the view of the Moho evolved. The changes in the acquisition parameters have translated in a direct increase in the overall resolution of the images. Smaller station spacing have increase the lateral resolution, higher source frequencies (coupled with an increase in the sampling rates) have increased the vertical resolution. Therefore, 100 years after its discovery controlled source seismic data has provided the Moho with an internal structure and local topography. A very complete review of the knowledge on the Earth's Crust and Lithosphere achieved by the refraction/wide-angle reflection profiling can be found in Prodehl and Mooney (2012).

\section{Normal Incidence Seismic Reflection}

Since the early 50's near vertical incidence (zero offset) multichannel recordings of the backscattered acoustic wave-field were attempted by using quarry blast in a number of places. Spatially dense near offset seismic recordings, now known as seismic reflection profiling method (Common Mid Point -CMP-), were used for exploration of natural resources (oil and gas). Reich (1957) and Dohr (1957) reported the identification of events in shot records as seismic phases, reflections, from intra-crustal horizons and in particular from the Moho. Similar events were also recorded by exploration companies near the Munich Basin and other Alpine foreland basins of southern 
Bavaria (Liebscher 1962). Elsewhere during the 1960s, the seismic reflection method was being directly applied to study the crust and the Moho (Beloussov et al. 1962; Dix 1965; Clowes et al. 1968). Since these early studies seismic reflection profiling has provided images of the crust-mantle boundary which are characterized by their richness in detail. The details in the pictures are considered to be the interference response of the source signal and the backscattered energy by the impedance structure of Moho itself. A relatively large number of academic seismic reflection research programs have been developed world wide. These have established the present high resolution knowledge on the characteristics and nature of the Moho (examples of these programs are: ECORS (France); COCORP (USA); DEKORP (Germany); LITHOPROBE (Canada); BIRPS (UK); ESCI (Spain); FIRE (Finland); among others). Currently Geoscience Australia and SINOPROBE (China) are carrying out dedicated seismic characterization programs resulting in high quality CMP images of the crust and upper mantle. These CMP data sets are specially rich and include studies developed across: different tectonic regimes; different geologic scenarios and have sampled terranes of different ages. Thus CMP profiling provided the means to map the Moho topography, and more importantly to obtain detailed images which place constraints to the internal structure and physical properties of the rocks in the vicinity of the base of the crust.

CMP data have provided the most highly resolved images of the crustmantle transition and, have shown that the Moho can vary from a relatively simple interface, to a very complex, vertical extended, and lateral variable set of reflection pulses, and in places even lack a reflection signature (Mooney and Meissner 1992; Hammer and Clowes 1997; Carbonell et al. 2000, 2002; Cook 2002; Cook et al. 2010; Giese 2005; Eaton 2006). The analysis of the back scattered wave-field indicated that the reflection character of the Moho can be the result of a wide range of possible structures, compositions, thermal evolutions, and formation processes. The CMP transects acquired world wide regardless the differences in the acquisition and processing parameters have revealed a series of general characteristics. The crust in this images is generally more reflective than the mantle (Hammer and Clowes 1997; Cook et al. 2010). The Moho is considered to be the last, deepest, relatively strong reflection which appear at similar depths (and/or time). Although, differences can partially be related to the evolution of the instrumentation technology and data acquisition geometry the variation in the seismic signature of the Moho is most probably independent of the surface geology and/or the age of 
the terranes that overly it. The near-vertical, deep seismic reflection images acquired by the different research teams throughout the world feature the Moho as a structure with a wide variety of reflection signatures (Oliver 1982; Klemperer et al. 1986; Prossen 1991; Carbonell et al. 2002). The continental Moho is most probably an evolving dynamic structure its geometry and location as well as its character are results of the most recent tectonic and/or thermal event in which it was involved (Jarchow and Thompson 1989; Hammer and Clowes 1997; Carbonell et al. 2002; Cook 2002; Cook et al. 2010). The Moho has variable seismic signatures. It can be identified in some cases as a single event; in others it is defined as a band of reflectivity of finite width; in others is considered to be the limit or transition from a zone of relatively high reflectivity to a transparent zone.

Presently, only a qualitative comparison between seismic signatures of the Moho obtained by the different research programs is pursued. Because there are fundamental differences in the acquisition and processing steps. The technology, hardware, design and parameters usually differ between projects. For example, stacked images have most probably been processed using different datums, this will result in differences in Moho depths due to the choice of the datum level. This differences can be as large as 1.5 to $2 \mathrm{~s}$. Perhaps unique and most consistent CMP data sets are the ones acquired by the research programmes of Geoscience Australia (in Australia) and LITHOPROBE (in Canada). These programmes have produced very high quality and internally consistent CMP data. A Large effort was devoted to maintain the data quality and homogeneity within the acquisition and processing parameters among the data corresponding to the different transects (Goleby et al. 1997; Cook et al. 2010). Both efforts have resulted in the most consistent seismic reflection sampling of the Precambrian lithosphere.

\section{Receiver Functions}

The visualization of the upper mantle and in particular the topography of the Moho has also been carried out through analysis of seismic records acquired by broad band sensor networks. Seismic Imaging with array recordings, has been evolving over the last decade. It is based on the use of converted seismic phases to display and characterize variations of physical properties within the crust and upper mantle (Fig. 4). The analysis of converted waves, are an asset to produce low resolution seismic images of the crust 
and upper mantle. Mainly the determination of the Moho by using receiver functions uses a relatively dense mesh of broadband seismometers.

Receiver function's terminology (Receiver Function, RF) was introduced by (Langston 1979) who describes these records and stacking procedures. Rondenay (2009) presents a detailed description of the processing steps to follow to obtain a RF image using converted and scattered teleseismic waves (Fig. 4). The key idea in RF imaging is the use of the converted phases. Seismic energy at teleseismic distances arrives at the receiver array as a plane wave. This plane wave travels upwards and interferes with the Moho (Fig. 4). The Moho interface represents the largest contrast in physical properties, the physical properties (seismic $\mathrm{P}$ and $\mathrm{S}$ wave velocitites and density $-\rho-$ ) of the crust against the physical properties of the mantle. Following the ray theory approximation as the $\mathrm{P}$ wave impacts the Moho interface the energy partitions into reflected and transmitted waves as described by the physics in the Zoeppritz equations (Aki and Richards 1980). The upward transmitted waves are the ones recorded by the array of receivers. The first phase to arrive at the receiver array will be the $\mathrm{P}$ wave while the other prominent phase should be the $\mathrm{S}$ phase converted (Ps) at the Moho boundary (Fig. 4). The depth of the Moho discontinuity can be estimated from the difference between the arrival times of $\mathrm{P}$ phase (direct wave) and the converted phase Ps. An estimate of the contrast in physical properties of the interface can be determined from the relationship between the amplitudes of the two phases. $\mathrm{RF}$ use these phases for the direct visualization of structure (Vinnik 1977; Langston 1979). To increase the signal-to-noise ratio of the converted phases, station records from multiple sources are combined by summing the records once they are normalized to the source and displaced in time depending on its angle of incidence.

For RF imaging an array of seismic stations with relatively small station intervals (on the order of a few km's) is required, the station spacing is responsible for the lateral resolution of the image, while the number of teleseismic records (redundancy) acquired in each station is responsible for the robustness of the observations. Note that the models are assumed to be one-dimensional, this implies that beneath the study area horizontal layers are considered. This simplification of the theory is valid in the low resolution case of the first order discontinuities such as the Moho.

The frequency content of the teleseismic records is very low when compared to the controlled source seismic data. The difference is, at least, of one to two orders of magnitude. Therefore, this technique is not able to resolve 
high resolution structure of the Moho boundary, although it can provide relatively reliable maps of its topography. Small dimension heterogeneities will be responsible for diffractions (and/or scattering) of the incident wave. Heterogeneities will generate a scattering field when their size is within one order of magnitude smaller than the magnitude of the predominant wavelength of the teleseismic signal (Fig. 4).

The deployment of recording devices with a relatively high spatial density (for example with a station spacing of $3-5 \mathrm{~km}$ ) has resulted in data that is suitable for the use of migration algorithms and other processing techniques which were developed for conventional controlled source, exploration seismology. The converted phases (Ps) once they have been corrected (normalized, rotated, etc) they are sorted into common conversion points, projected to depth and stacked (Dueker and Sheehan 1997; Kosarev 1999). This is equivalent to the CMP sorting and stacking of the exploration seismology. The resolution can be further increase by using more complex imaging operators there is a relatively long list of new developments in this field (Revenaugh 1995; Bostock and Rondenay 1999; Ryberg et al. 2000; Sheehan et al. 2000; Shragge et al. 2001; Poppeliers and Pavlis 2003; Frederiksen and Revenaugh 2004).

Currently the acquisition of passive source seismic data is being carried out extensively. Relatively large networks consisting of regularly spaced broad-band sensors are being deployed within ambitious multidisciplinary projects such as: EARTHSCOPE (USA); TOPOIBERIA-IBERARRAY (Spain); SINOPROBE (China), AUSSCOPE (Australia) among others. These large scale arrays of receivers a being complemented by local research initiatives with the aim of increasing the lateral resolution in specific and key structural study areas.

\section{Multi-seismic signatures of the Mohorovičić Discontinuity}

\subsection{The Moho under Paleozoic Mountain Orogens}

\subsubsection{From the Appalachians to the Urals}

The Appalachians are considered jointly with the Caledonides and the Variscides typical Paleozoic orogens. The seismic characteristics of the Moho beneath this collisional tectonic setting, is relatively complex and varies laterally. A description of the discontinuity beneath the Southern Appalachians can be found in Nelson et al. (1985). Beneath this late Paleozoic orogenic belt of southeastern US the Moho is relatively horizontal and is discontinuous 
across the orogen (Pratt et al. 1988). These early references already identify as the Moho discontinuity the base of the layered reflection sequence which is attributed to a laminated lower crust (Pratt et al. 1988).

The Moho topography and its seismic signature beneath the Northen Appalachians (Newfoundland) has been described from early refraction and CMP data (Hughes et al. 1994). The wide-angle PmP reflection is clearly observed at 100-140 km offset. The depth of the refraction Moho correlates with the base of the reflectivity in some parts of the early CMP transects acquired in the area. The discontinuity changes laterally in depth and in seismic signature. The reflection Moho varies from well defined, high amplitude and a laterally continuous reflection fabric to an interpreted Moho as the base of the crustal reflectivity. This lower crustal reflectivity in some cases can define a dipping fabric, which can reveal different geometrical relationships with the Moho boundary, it can coalesce into the Moho or it can be truncated by the Moho. These relationships are highly dependent on the processing strategies. A detailed and complete description of the Moho beneath Canada constrained by the LITHOPROBE transects can be found in Cook et al. (2010).

The Collision between Gondwana and Baltica in the Late Palaeozoic is represented in Europe by the Variscan orogenic belt. It extends from southwestern Iberia Peninsula, across the Massif Central (France) to the East European Platform. Three tectonic terranes were involved in the orogeny. In southwestern Iberia, the Orogen is a major transpressive collisional feature which has been investigated by multi-seismic (controlled and passive source) data acquisition experiments. The controlled source IBERSEIS experiments (Fig. 5) include CMP Vibroseis (Simancas et al. 2003; Carbonell et al. 2004) and spatially dense wide-angle seismic reflection profiles (Palomeras et al. 2009; Flecha et al. 2009; Palomeras et al. 2011). The passive source data for the $\mathrm{RF}$ images is provided by the TOPOIBERIA project.

The Moho is located at $11 \mathrm{~s}$, TWT in the CMP image it is coincident with zero offset recordings of the wide-angle explosive shots (Fig. 5). $11 \mathrm{~s}$ corresponds to an approximate depth of $30-33 \mathrm{~km}$. The Moho is horizontal and located at constant depth. Its seismic signature changes laterally. For example, in the wide-angle, the PmP phase at near offset changes in frequency and amplitude depending on the location of the shot point with respect to the dominant geological terrane. Beneath the Southern Portuguese Zone the $\mathrm{PmP}$ is a sharp and high amplitude event characterized by a short and simple wavelet (Fig. 5) it can be interpreted as the reflection response due to a sim- 
ple structure which is close to a step discontinuity (Palomeras et al. 2009). The CMP image beneath this South Portuguese Zone (southern end of the IBERSEIS profile) reveal a Moho as a relatively thin high amplitude reflective band. Some dipping events in the lower crust (Fig. 5 coalesce toward it at $11 \mathrm{~s}$ (Simancas et al. 2003). The wide-angle shot gathers reveal relatively high reflectivity at mid-to-lower crustal levels, and the PmP correlates with the base of this reflected energy (Flecha et al. 2009). In comparison, the towards the center of the profile (beneath the Ossa Morena terrane) the Moho is relatively weak and discontinuous (Fig. 5). When it is observed, the event is 0.5 to $1.0 \mathrm{~s}$ thick suggesting that the Moho is a relatively thick feature with a complex internal structure (Simancas et al. 2003). Towards the northern end of the transect (beneath the Central Iberian Zone) the CMP Moho is also characterized by relatively high amplitude band of reflectivity (Fig. 5), beneath a boudinage like lower crust (Simancas et al. 2003). Farther to the north, Martínez Poyatos et al. (2012) image the Moho as a high amplitude horizontal band of reflectivity located at $10 \mathrm{~s}$ TWT (Fig. 6). The Moho is interpreted to correspond to the sharp break in the reflectivity, the base of the reflective lower crust. Towards the south of this transect (Fig. 6) a prominent high amplitude dipping event penetrates the upper mantle. Imaging, a crust-mantle wedge.

Sample images of the Moho beneath the Caledonides were obtained by the BIRPS program within several deep seismic reflection lines such as for example: the MOIST, DRUM, GRID's etc. (Brewer and Smythe 1984; Snyder and Flack 1990; McBride et al. 1995). In general the Moho is well imaged as an, approximately sub-horizontal $0.5 \mathrm{~s}$ band of high amplitude reflectivity (Fig. 7), located at approximately $25 \mathrm{~km}$ depth. It is considered to be a structure of finite thickness and with internal architecture. The multiseismic data acquired in the area north of Scotland (Fig. 7) is mutually consistent. The RF data, although it was acquired between 40 to $60 \mathrm{~km}$ away from the CMP, provide low frequency images with a relatively thick structure, which coincides in depth (time) with the mapped Moho by the controlled source data (Fig. 7). An expanded spread was also acquired in the area suggesting that the Moho is a 0.5 s thick feature. The relatively low frequency $(<18 \mathrm{~Hz})$ of the marine controlled source used is indicative of a layered structure. A peculiar feature of the these transects and other deep seismic reflection profiles acquired in the British Caledonides is that the Moho is intersected by a high amplitude band of dipping reflectivity (Hynes and Snyder 1995). One of the highest frequency images ever acquired of the crust-mantle transition 
was obtained also under the Caledonides. Warner et al. (1994) used explosive and deeply buried sensors, this acquisition designed allowed recording signal characterized by frequencies over $100 \mathrm{~Hz}$. The images provide evidence of a highly structured Moho transition, at least in the southern UK Warner et al. (1994).

In the central European plate the DEKORP program also targeted Variscan orogenic structures (for example with the DEKORP 2-N, GRANU '95 profiles). The Moho is located at a nearly constant depth of $30 \mathrm{~km}$, with locally relatively small variations. For example, in the southernmost portion of DEKORP 2-N the Moho is located at about $26 \mathrm{~km}$ limiting the highly reflective fabric of the lower crust. and increases in depth towards the northwest to more than $30 \mathrm{~km}$. Similarly to what is observed in the - ECORS N̈ord de la France - profile which samples a similar tectonic zone located to the west (Bois, C. and ECORS Scientific Party 1990). Also In the DEKORP 2-N beneath the central and southeastern parts of the profile the Moho is marked by distinct reflections at about 9 to $9.5 \mathrm{~s}$ TWT. Below these reflections a finite band of energy is observed which might be indicative of a transition zone, rather than a simple discontinuity as consistent with previous refraction studies (Mechie et al. 1983) in the area. This is an example of two alternative interpretations suggested by two different types of seismic reflection data sets. This contrasts with interpreted Moho along the DEKORP 1B profile (1987) where it is not imaged and it is assumed to be at about 10 s TWT due to the lack of reflection energy below 10 s TWT. (Oncken 1998; Franke et al. 2000)

The Urals mountains are another example of Variscan orogen which has also been investigated by seismic methods (e.g. ESRU Juhlin et al. (1996); Druzhinin et al. (1997); Juhlin et al. (1998) and URSEIS'95 (Berzin et al. 1996; Carbonell et al. 1996; Echtler et al. 1996; Knapp et al. 1996). Projects) (Figs. 8 and 9). Unlike other Paleozoic orogenic belts the Urals have not undergone post-orogenic extensional collapse and are relatively well preserved for its age. A relatively well constrained crustal root has been imaged by the refraction/wide-angle experiments in the central (Juhlin et al. 1996) and southern Urals (Carbonell et al. 2000) (Figs. 8 and 9). The root in the southern Urals is constrained by $\mathrm{PmP}$ and $\mathrm{SmS}$ phases (Fig. 9). The CMP image of the Moho is a laterally variable. It is a relatively high amplitude and sharp event with moderately complex wave train at both ends of the profile (Fig. 8). Beneath the former East European Craton (in the west) and beneath the accreted terranes of the Trans- Uralian Zone (in the east). The 
Moho is not visible beneath the core of the orogen in the CMP images (Fig. 8). This is the area underneath the Magnitogorsk Volcanic Arc. The Moho signatures along the CMP transects have been correlated to the different terranes that outcrop at the surface (Carbonell et al. 2002). The structural model for the Moho accounts for the lateral variability of the reflectivity signature as well as for the, lack of normal incidence reflectivity. This latter feature is taken as evidence for a transitional Moho (gradient velocity model) (Carbonell et al. 2002) beneath the root zone which can be imaged by wideangle reflection data(Fig. 9).

\subsection{Across the Trans-European Suture Zone: From Central to North and Eastern Europe}

From Central to North and Eastern Europe the Trans-European Suture Zone (TESZ) is a prominent geological feature it limits the mobile Phanerozoic terranes in the south and west from the Precambrian East European Craton. It is an enigmatic element in the evolution of the Paleozoic European orogens. Geophysical constraints have been established through a series of research efforts, (Thybo et al. 1999, 2002). The multiseismic studies carried out across this feature together with geophysical experiments across the Urals, have brought new insights in the topography, nature and evolution of the Moho across a major suture zone. A large effort has been devoted to the Central and North-Eastern Europe in acquiring deep seismic reflection data to constrain the structure of the crust and upper mantle in the boundary area from the East European Craton across the Trans-European Suture zone to the Variscides. This area has been the target of a series of wide-angle seismic reflection data acquisition efforts well know examples include: POLONAISE' 97 (Guterch et al. 1999; Jensen et al. 1999, 2002; Grad et al. 2002; Czuba et al. 2002; Janik et al. 2002) CELEBRATION 2000 (Guterch et al. 2003b, a; Ržek et al. 2003; Grad et al. 2006; Majdanki et al. 2006; Grad et al. 2006) SUDETES 2002 (Majdanki et al. 2006; Kryza and Zalasiewicz 2008; Geissler et al. 2012; Grad et al. 2008) GRUNDY 2003 (Malinowski et al. 2007; Malinowski 2009). A complete assessment of these data can be found in Prodehl and Mooney (2012).

The Moho depths increase across the TESZ from approximately $30 \mathrm{~km}$ beneath Phanerozoic Europe to, approximately, $45 \mathrm{~km}$ beneath the Precambrian craton. This general trend of increase in crustal thickness towards the Precambrian craton of East Europe has been seismically mapped at different latitudes. This trend is observed beneath Sweden, by the SCANDES 
wide-angle experiment (Stratford and Thybo 2011). Grad et al. (2006) documented similar variation in Moho depth and lithospheric velocity structure across the TESZ using the refraction/wide-angle reflection experiments, for example the CELEBRATION line 5 which reveals the increase in thickness and a relatively high velocity layer at the base of the crust beneath the Precambrian craton of east Europe. Broad band recordings of teleseismic events acquired in the TOR experiment (Gregersen and Voss 2002) also support this increase in thickness. In southern latitudes Geissler et al. (2012) also maps this features. Teleseismic and regional earthquake tomography data define a complex suture in the mantle beneath the TESZ the transition from a thin, normal crust to a thick crust beneath the Precambrian craton. A change in the internal structure of the Moho is also expected when going a cross the TESZ (Wilde-Piórko et al. 2010). However, the low frequency that characterizes the recordings of the passive broad-band sensors is not able to resolve this features.

The transition from TESZ to the Variscan Orogen of Central Europe has been targeted by muti-seismic data acquisitions, for example the SUDETES and the GRUNDY experiments. These reveal a Moho with a laterally variable seismic signature. The GRUNDY 2003 seismic images (Malinowski 2009) characterize the seismic reflection fabric of the lower crust (20-23 km depth) as featuring a high amplitudes. The comparison of the refraction and the wide-angle reflection data favored that the Moho could be associated to the base of the prominent reflectivity at $11 \mathrm{~s}$. The mapped increase in depth towards the east of Moho interface and the relatively high velocities determined there at base of the crust and upper mantle lead Malinowski (2009) to suggested possible eclogite facies rocks at the base of the crust in the root zone of the Precambrian craton.

\subsection{Transects Across Precambrian Terranes}

The FENOLORA experiment acquired data in the Precambriam of Northern Europe in late 80's (Clowes et al. 1987; Prodehl and Mooney 2012) in Sweden and Norway. The Moho in this data set was interpreted to be a $7 \pm 2$ $\mathrm{km}$ thick zone which increases in depth from 40 to $50 \mathrm{~km}$. Locally along the profile the Moho features depths in excess of $55 \mathrm{~km}$ (beneath Norrkoping and Sundsvall, Sweden). This seismic transect is another example of la laterally variable Moho, in depth an in thickness. Its depth varies approximately 12 $\mathrm{km}$ from North to south and changes from a relatively thick transition zone to a relatively sharp step discontinuity. In the 90's high quality seismic data of 
the BABEL and FIRE projects delivered examples of the Moho beneath the Precambrian crust of the European Plate. As in Canada and Australia there is a well defined reflectivity observed in some parts of the Precambrian shields that have undergone Proterozoic orogenies, extension, and basin formation (BABEL Working Group 1990, 1993a; Kukkonen and Lahtinen 2006). The Moho is defined as the base of the relatively strong band of reflectivity interpreted as the lower crust, and has an irregular topography (Figs. 10 and 11). It is highly variable going from very distinctive and sharp limit of reflectivity to areas where it is not defined. These changes can happen within 10's of $\mathrm{km}$. The Moho depth ranges from about $30 \mathrm{~km}$ beneath northern Germany to $62 \mathrm{~km}$ beneath the Bothnian Sea and, with a prominent root beneath the southern Bothnian Bay (Figs. 10 and 11). When compared with refraction data (FENOLORA) the mapped reflective Moho is difficult to correlate to the refraction Moho (BABEL Working Group 1990, 1993b; Riahi et al. 1997). The CMP and the refraction acquired in the area constitute an example of a lack of correlation for what is related to Moho depth and topography. RF images from Alinaghi et al. (2003) using broad band records which have been acquired by the seismic networks: TOR, SCEKALAPKO, GRSN and GEOFON; reveal a well defined Moho nearly horizontal southwest of the TESZ limit (Figs. 10 and 11). The Moho northeast of the TESZ features a sharp increase in depth to values near $60 \mathrm{~km}$ (deeper than mapped by controlled source seismic data).

Across the Atlantic, the LITHOPROBE research programme constrained the Lithosphere beneath Canada with a series of integrated transect. Implications of this unique data set on the structure and nature of the Moho has been extensively discused (Hammer and Clowes 1997; Cook 2002; Eaton 2006; Cook et al. 2010; Oueity and Clowes 2010). The Archean tectonic terranes of the Abitibi province feature a Moho that shallows from 40 to 32 $\mathrm{km}$ within the Superior Province and contrast with the Moho depth beneath the Grenville Province which averages in depth of (44 $\pm 2 \mathrm{~km}$ ) (White et al. 2000). Flat relatively simple and horizontal Moho is imaged beneath the Opatica belt which contrasts with a transparent Moho beneath the Abitibi belt. Relatively large differences for the depth of the Moho discontinuity are found in adjacent parts of the Midcontinent Rift and these variations are uncorrelated with surface topography. The Moho is the deepest beneath the central Graben at $55 \mathrm{~km}$, at the margins of the rift the Moho appears to be at approximately 35 to $40 \mathrm{~km}$. Another contrast in Moho depth is mapped beneath the Grenville front in southern Ontario with a transition from 45 
to $35 \mathrm{~km}$ beneath the Grenville orogen and the Superior Craton respectively (White et al. 2000). Beneath the Superior craton the Moho is predominantly horizontal, and it is deepest beneath the Kapuskasing structure (Darbyshire et al. 2007). Calvert et al. (2004) imaged the shallowest Moho beneath the Western superior province beneath the western part which is estimated at $32 \mathrm{~km}$ depth. RF images are consistent with this measurements revealng relatively large variations for the depth of the Moho that range from approximately $32 \mathrm{~km}$ to depths $45 \mathrm{~km}$. The Moho is once more characterized by a sharp transition in the reflectivity fabric, from highly reflective for the crust to a nearly transparent for the upper mantle (White et al. 2003; Calvert et al. 2004; Van der Velden and Cook 2005). The Moho beneath can be associated also to a conspicuous, nearly horizontal reflector denoting the base of the crust a relatively thin transition zone. Beneath the Western Superior, wide angle reflection data reveal a prominent Moho reflection (Kay et al. 1999) in contrast with the CMP Moho which is mostly associated to the transition from a reflective crust to a mostly transparent upper mantle (White et al. 2003)

Under the Trans Hudson Orogen seismic data defines a clear root beneath the Reindeer which exceeds $40 \mathrm{~km}$ depth. The Moho is shallower at both sides. The upper mantle velocity beneath the Trans Hudson Orogen, in one direction is anomalously high $(>8.6 \mathrm{~km} / \mathrm{s})$. Locally, in the other direction low velocities of $8.1 \pm 0.1 \mathrm{~km} / \mathrm{s}$ where estimated from other refraction studies. This favored and interpretation in terms of anisotropy which appears to be confined to a small volume within the overall study area, perhaps due to the complex tectonics that occurred in the area (Németh et al. 2005).

It is difficult and most probably not correct to emplace and/or discuss the results of LITHOPROBE concerning the Moho beneath Canada under a single caption related to a geologic time scale as it is done in this contribution. LITHOPROBE results in Northwestern Canada revealed a complex crustal lithosphere, for example, evidences of precambrian crust where constrained beneath the Mesozoic northern Canadian Cordillera (Cook et al. 2004) by the Slave-Northern Cordillera Lithospheric Evolution (SNORCLE) transect (Fig. 12). An integrated view of the lithosphere beneath the northwestern Canada can be found in Cook et al. (2004); Clowes et al. (2005). These contribution present a detailed description of the seismic data results and a discussion of their implications. The CMP images reveal a laterally variable Moho across this Precambrian terranes (Fig. 12). It is determined by the base of the reflectivity in the western part of the transect, it is marked by a 
relatively thin band of laterally continuous reflections in the central part of the transect and it is weaker and more discontinuous towards the western end of the image. Additionally the CMP data reveals that the crust is slightly thicker in the center of the image beneath the Wopmay Orogen (Fig. 12). The wide-angle data (Clowes et al. 2005) reveals a relatively consistent Moho at 30-34 km depth all along the transect (Fig. 12).

In southern Alberta the extensive seismic data base places strong constraints on the Moho depth. Lemieux et al. (2000); Clowes et al. (2002) discuss the results for Southern Alberta, and the transition towards the Wyoming Province, where the lithosphere was constrained by the SALT and SAREX seismic experiments. The Moho in the northern part is relatively horizontal and located at an approximate depth of $35 \mathrm{~km}$. Towards the South the crustal thickness increases up to values of 56 to $58 \mathrm{~km}$ towards the Archean Wyoming Province in Montana (Clowes et al. 2002). Beneath South Alberta the teleseismic data (Eaton and Hope 2003) does not provide enough evidences for the prominent step at the Moho indicated by the seismic reflection data located just beneath the Great Slave Lake Shear Zone.

In summary beneath Precambrian terranes the seismic signature of the Moho is highly variable. For instance: in a large number of studies the crust mantle boundary is considered to be represented by the sudden change between the reflective fabric of the lower crust and the transparent upper mantle; in others the Moho is interpreted to be represented by a band of reflectivity, packets of reflections with some lateral continuity of a few 10's of $\mathrm{km}$; furthermore there are studies where no significant evidence of a crust-tomantle transition is present. Cook et al. (2010) presents a more detail review of the Moho across Canada.

\subsection{The Moho Under Late Mesozoic Orogens}

\subsubsection{The Canadian Cordillera}

Beneath the west coast of Canada, LITHOPROBE results reveal that the Moho shallows to values approaching $10 \mathrm{~km}$ depth (Hammer and Clowes 1997; Clowes et al. 2005). A unique Moho reflection was not identified in the seismic sections beneath the Vancouver Island and in the western Coast Mountains (Clowes et al. 1987). Clowes et al. (1987) identified two marked reflective zones as the top and bottom of the Juan de Fuca plate, however, few reflections from the down-going plate can be observed in the reflection section, the wide-angle/refraction data was needed to constrain the geometry. With respect to the structure beneath the Vancouver Island the position 
of the down going slab as identified from the controlled source data (normal incidence and wide-angle seismic reflection data) is questioned by the results from teleseismic studies (based on converted phases and suggested anisotropy) (Nicholson et al. 2005) who place the top of the Juan de Fuca plate $10 \mathrm{~km}$ shallower than in the previous seismic studies. Therefore a continental Moho in an unresolved issue in this area.

\subsubsection{The Alpine-Himalyan Orogens}

The Alpine-Himalayan orogenesis developed along the boundary of two megaplates during the closing of the Tethis. These orogens include, from west to east, for example: the Atlas, the Betic-Rif the Pyrenees-Cantabrian, the Alps, the Carpathians, the Caucasus, the Zagros, the Hindu-Kush, and the Himalayas among others. Seismic data across these orogens is available from which the main characteristics of the Moho can be assess. The CMP seismic image acquired across the Pyrenees, (Choukroune and Team 1989; Roure et al. 1989; Choukroune et al. 1990) reveals a highly variable topography of the Moho boundary (Fig. 13). A near horizontal Moho is well defined by reflectivity packages at both sides of the collision zone beneath the Northern and Southern ends of the line (at both sides of the axial zone). Under the axial zone a well developed step can be interpreted with an offset $>10$ $\mathrm{km}$ (Fig. 13). This offset in the Moho correlates at the surface with the outcrop of the North Pyrenean fault (Fig. 13). At depth a relatively high amplitude north dipping reflector delineates an inclined thick slab defining an indentation of the European plate in the Iberian subcontinent, a wedge structure. The cross-section lacks continuity of the Moho beneath the core of the orogen. The Moho beneath this axial zone was constrained by the previously acquired refraction data. In detail the southern horizontal Moho (beneath the Ebro basin) features a distinct character when compared to the also well defined Moho beneath the northern end of the line (beneath the Aquitaine basin). Recently acquired passive source recordings to the west of the main CMP transect have provided RF images (Fig. 13) revealing a crustal scale indenter wedge structure (Díaz et al. 2012). A prominent and relatively thick Moho beneath Iberia is dipping towards the north. Approximately, in the vertical of the Axial zone a prominent step in the Moho is suggested by the RF images.

The Alps have been also the target of several deep seismic reflection transects. The Moho in NFP20 (Pfiffner et al. 1988; Valasek et al. 1991) appears as a series of bright reflection that steepens from the north toward the south 
and terminates abruptly near the center of the Alpine chain (Pfiffner et al. 1988; Valasek et al. 1991). To the east the Moho is further constrained by the TRANSALP profile (Castellarin et al. 2006) This is a recently acquired multi seismic research initiative which includes a CMP profile across the Eastern Alps (Fig. 14). This CMP image visualizes the European Moho descending regularly, delineating a zone that projects south of the Periadriatic Lineament. The Moho boundary and its geometry are well marked in the seismic profile. The Moho is interpreted in this case as the base of a reflective lower crust. The European Moho can be followed from $30 \mathrm{~km}$ depth, under the northern Molasse foreland, down to about $55 \mathrm{~km}$ depth south of the higher mountains of Alps then it disappears, to appear again towards the southern part defining a Moho step of over $10 \mathrm{~km}$ (Fig. 14). Cassinis (2006) located the Moho at about $40 \mathrm{~km}$ depth, in the Belluno area this depth is consistent with previous refraction data interpretations and also with the RF (Fig. 14) data acquired coincidently with the TRANSALP CMP transect (Kummerow et al. 2004). The Moho is mapped at depths of only 25-30 km near Verona in the southern end of the profile, it features a dipping attitude towards the west and south The relatively old refraction data set interpreted by Deichmann et al. (1986) mapped a lower crustal doubling, to the west and north. The European Moho is characterized by a relatively high southern dip. The overall image suggests a wedge structure, similar to the one imaged across the Pyrenees (Fig. 13). Further constraints on the Moho beneath the Western Alps were obtained by the joint ECORS-CROP transect which revealed a similar step discontinuity. According to the TRANSALP RF images the Moho is an, approximately, $10 \mathrm{~km}$ thick structure. The CMP reveals the Moho as a 2-3 s thick band of high amplitude reflectivity which displays lateral continuity over distances of $30-40 \mathrm{~km}$. The Moho in both images (CMP and RF) is discontinuous beneath the southern flank of the orogen, revealing a step of $>10 \mathrm{~km}$. Alpine orogens reveal a prominent vertical step. This is probably fundamental structure which has also been reported in the case of the Tibet-Himalayan collision zone.

The Himalayan Mountains because of its significance has been extensively studied. Early refraction studies (Allegre et al. 1984; Hirn et al. 1984) suggested a prominent Moho step of $20 \mathrm{~km}$, a sharp depth variation of the boundary from $50 \mathrm{~km}$ to $70 \mathrm{~km}$. At surface this step correlated with a geologically prominent limit the boundary between two continents. Beneath this unique collision zone the refraction data revealed a complex Moho surface the seismic reflection pattern observed in these early seismic refraction 
recordings revealed an interpreted PmP characterized by several jumps (discontinuities) revealing a rugged topography and/or Moho duplications. This refraction seismic signature was interpreted as a crustal scale thrusting (duplexing). The international seismic research program INDEPTH was able to produce images of the Moho by wide-angle and CMP data. The INDEPTH CMP profiles exhibit relatively few reflections from the crust beneath a high amplitude reflection at 15 - to 20-km-depth (Nelson et al. 1996). This CMP section maps the Moho only locally near the southern end of the transect (Fig. 15). Beneath the Gangdese batholith at depth a steeply north-dipping reflection is imaged. To the south, the former reflector is not seen and the crust is characterized by a high amplitude reflectivity signature the Moho which has been interpreted to be the base of the 75-80 km-thick crust beneath the Tethyan Himalaya. The Moho is interpreted to be at a depth of, approximately $75 \mathrm{~km}$. To the north, other seismic methodologies are required to constrain its position (Kosarev 1999; Nábelek et al. 2009; Kind and Yuan 2010). Receiver function data constrained the Moho at similar depths of about 75 and $80 \mathrm{~km}$ (Fig. 15). These depth estimation suggest that the Moho features a slight increase in depth toward the north beneath the Central Tibet. Consistent with a Moho step suggested by previous refraction, wide-angle recordings (fan-records) (Allegre et al. 1984; Hirn et al. 1984, 1995).

The combination of these seismic dataset suggests that the Moho in this Orogenic belt features a large amount of complexity. The three examples of passive and controlled source seismic data of Fig. 15 reveal prominent lateral variations in the structure of the Moho in its topography, depth, thickness, indicative of prominent changes in its physical properties. For example, the INDEPTH CMP reveals two 0.72-1.0 s thick prominent reflections one at approximately $10 \mathrm{~s}$ and another at $20 \mathrm{~s}$ (interpreted as a double Moho). These events which are relatively continuous structures in the southern end of the line for at least $60 \mathrm{~km}$ dip towards the north (Alsdorf et al. 1998). To the west of the INDEPTH study area RF image resulting of the HiCLIMB experiment (c in Fig. 15). The Moho of the Indian plate is located at approximately $40 \mathrm{~km}$ depth (Nábelek et al. 2009). It is a relatively thin structure beneath the Indian plate and it increases in thickens and depth towards the north. Between $29^{0}$ and $31^{\circ}$ Latitude at a depth of $60-70 \mathrm{~km}$ there is a $200 \mathrm{~km}$ long horizontal lens revealing a double Moho (Fig. 15). Towards the north the Moho weakens, and it even disappears (at a latitude of $32^{0}$ ), at $33^{0}$ the Moho is visible again as an approximately $10 \mathrm{~km}$ thick 
structure Nábelek et al. (2009). Similar RF images have been obtained by Kind and Yuan (2010) along the INDEPTH study area (Fig. 15). Note that a double Moho, is also observed in this image at approximately the same location as the HiCLIMB images. The resolution of this images is not high enough to reveal if this $200 \mathrm{~km}$ long lenticular feature (double Moho) is a low frequency image of the previously interpreted lateral stack of Moho imbrications as suggested by the interpretations of the early refraction data (Allegre et al. 1984; Hirn et al. 1984, 1995).

\subsection{The Moho beneath Rift and Extensional Tectonic Regimes}

Precambrian terranes of Europe include extensional structures including the Oslo Rift, and the active Pripyat-Dniepr-Donets rift (Stephenson 2004) Beneath this structure limited amount of seismic data is available. Constraints on the depth were obtained from refraction data from DOBRE experiment ((Grad et al. 2003)). The smoothly undulating Moho centered at $40 \mathrm{~km}$ depth was defined by this high quality refraction data. The Moho in nearly all of the shot records can be identified starting at $70 \mathrm{~km}$ offset distance, as a relatively simple arrival. High velocities were determined beneath the axis of the Donbas fold belt.

Perhaps one of the most well studied zone with extensional tectonics is the Basin and Range in continental US. Across the Basin and Range province the reflection Moho is continuous. The COCORP $40^{\circ} \mathrm{N}$ delineated a relatively continuous Moho for, approximately, $800 \mathrm{~km}$ long line. This transect goes across geological terrains which experienced different tectonic evolutions before the Cenozoic (Klemperer et al. 1986). The Moho truncates other crustal seismic reflection fabrics suggesting that the Moho is a relatively young feature which has been overprinted to previous structures. Moho and lower crustal reflectivity is most prominent in continental areas characterized by extensional tectonic regimes, Basin and Range Province in western USA (Prossen 1991) and at passive margins.

Relatively horizontal Moho's have been defined beneath, relatively, large scale extensional domains. The Moho under extensional tectonics has also been interpreted to be a complex structure. Numerous times it appears as characterized by by relative thick pile of high amplitude reflection sequences, One of the most outstanding examples is the Nevada-PASSCAL experiment. The wide angle data revealed a strongly layered (laminated) Moho characterized by seismic anisotropy (Thompson et al. 1988; Carbonell and Smithson 1991). Similar proposed lensing has been modeled for Rift zones for example 
in the Baikal (Thybo and Nielsen 2009) and has been found to feature a limited lateral extension.

The Valencia Trough is another relatively young rift basin in the western Mediterranean. The Moho image by a wide-aperture two-ship experiment was traced across the basin. Differences in the reflection character of the lower crust and Moho where correlated (Collier et al. 1994) to differences in the amount of stretching. The base of the crust (lower crust and Moho) is imaged as a band of high amplitude reflectivity characterized by horizontal reflection segments. This band is approximately $4 \mathrm{~km}$ thick beneath the Iberian Margin then it thins considerably towards the center of the basin where only a prominent and thin Moho reflection is identified (Collier et al. 1994).

\section{Joint analysis of the seismic data: Constraints and Implications on the Moho}

The seismic data resulting from the different acquisition approaches (refraction CMP and RF), provide a complementary view on the Moho. In order to bring together the knowledge obtained on the Moho by these methods it is relevant to reconsider some of the existing difficulties in the interpretation in the methodologies. The Moho depths estimated from refraction/wide-angle seismic reflection when compared with the depths mapped by the normal incidence profiles are in most cases consistent although they might not be coincident. The similarities are due to the fact that the latter (normal incidence Moho depths) are generally derived from the refraction derived models. Nevertheless in cases were both kinds of data has been collocated (for example in the seismic data acquired with programs such as the URSEIS Fig. 8, 9; and IBERSEIS Fig. 5) the position of the reflection Moho (if visible) and the refraction Moho are close in the sense that the base of the reflectivity or the marked/prominent laterally continuous reflected events are observed at the normal incidence reflection travel times that would correspond to depths of the refraction Moho. In the detailed determination of the depth to Moho from refraction/wide-angle shot records differences can be detected depending on which type of phases are considered. In particular, PmP and $\mathrm{SmS}$ phases result in different depth estimates. This is because, although they have similar frequency content, the differences in wavelength $\lambda$ between both wave types make them sensible to distinctly different vertical correlation lengths. Because of this difference sensitivity in wode-angle images a 
structure can have different seismic signatures depending on which type of waves is used to illuminated it. Another potential difficulty in travel-time interpretations of wide-angle data may be in the fine determination of Moho depths by using diving waves (Pn phase) and reflected phases (PmP) (Zelt et al. 2003). This could be an issue if the Moho is a transition zone with some degree of heterogeneity and a finite thickness. Then PmP phase could correspond to backscattered energy of the upper part of the structure while a Pn phase would result of the interference pattern of far offset diffractions. The Pn would be a diving wave (refraction) which would constrain the base of the transition zone.

The influence of CMP acquisition parameters can result in different interpretations for the Moho. Source signal characteristics, amplitude and frequency content. Amplitude will affect the signal penetration, and the Moho may or may not be seen. This eventually has direct consequences on the interpretation of the Moho structure. The source frequency content, signals characterized by low frequencies make the Moho a simple structure, while signals with a broad frequency spectra feature a more complex Moho. Vertical resolution is a function of the source frequency and lateral resolution of the station spacing. In CMP images processing is a prime key player in the appearance of the seismic signature of the Moho. The final interpretation of the Moho is usually guided by the geometrical relationship of the Moho reflection with the features around it. The attitude of this features with respect to the Moho will suggest the interpreter different interpretations. Processing can make dipping reflections coalesce or truncate the Moho this can result in contrasting interpretations for the same structure (for example for the transect across the Newfoundland Appalachians (Hall et al. 1998; Van der Velden et al. 2004)).

In $\mathrm{RF}$ parameters that influence the interpretation are the azimuth of the incoming energy that illuminates of the structure, station spacing, and processing. For example different images have been obtained depending on the illumination azimuth for the Himalayas (Fig. 15). While the addition of multiply converted phases such a PpPms PpSms (Fig. 15), can increase the lateral resolution, each individual stack usually results in a different image as it reflects differences in the target interface and/or differences in the incoming wavelet.

$\mathrm{RF}$ images are characterized by relatively low frequencies the correlation between RF and controlled source images provide complementary views lacking major discrepancies. In order to increase the strength and number of 
constraints on the Moho multi-seismic (passive and controlled source) data is desirable. However, when attempting a joint and consistent interpretation additional difficulties appear. Moho depths determined from CMP and refraction/wide-angle need to be consistent as corresponding to the seismic signature of the same refraction/wide-angle and CMP images. There are a number of factors that contribute to depth differences: the datum to which CMP data is processed, the acquisition geometry which might not overlap. Wide-angle and CMP data are not usually acquired in the same field operation therefore, the station locations will differ from one field acquisition to the other (the profiles don't coincide). Secondly there are fundamental differences in the frequency content of the recorded signals; for example for the wide-angle (refraction) are typically lower frequencies than normal incidence reflection signals. In summary wave-forms from the different data sets (normal incidence, refraction and/or wide-angle reflection) will not match.

There is significant non-uniqueness in comparing the Moho structure imaged by these complementary seismic methods. Each type of data, because of the different signal characteristics places different constraints on the geometry and nature of the Moho discontinuity. The first implication of the description of the seismic images of he Moho across the distinct geologic and tectonic terranes of different ages, is that the Moho is an elusive structure. It is characterized by a variety of distinct seismic signatures at different resolution scales that currently prevent a sufficiently general model that can be universally applicable.

In general seismic data places the continental Moho at, approximately, $33 \mathrm{~km}$. Note that while Moho depth is similar world wide if features relatively large local differences for example it is found deeper than $>55 \mathrm{~km}$ and $<30 \mathrm{~km}$ in specific areas. Moho is deeper $(>39 \mathrm{~km})$ in active collision tectonic scenarios, such is the case of the Pyrenees, Alps, Urals, Himalaya orogens. In North eastern Europe a variation of over $15 \mathrm{~km}$ in Moho depth is observed across the TESZ, from the Phanerozoic Europe to, approximately, $45 \mathrm{~km}$ beneath the Precambrian craton, a similar situation has been mapped in Northwestern Canada by the SNORCLE project, a keel over $50 \mathrm{~km}$ has been also imaged beneath the Wyoming province in central USA. Thinner crust $<35 \mathrm{~km}$ is observed in the Archean Slave Province, Mesoproterozoic Wopmay Orogen. Archean and Proterozoic terranes in Australia (Goleby et al. 1990; Wright et al. 1990; Goleby et al. 2004) also show a variety of crustal thicknesses which range from 30 to $50 \mathrm{~km}$. Therefore any general/universal interpretation on the nature of the Moho needs to take into 
account the regularity in the average depth values for this boundary across terranes characterized by different ages and that, most probably have been affected by a complex evolutionary history of lithospheric processes. And, it also need to allow for relevant local depth variations, in some active orogenic belts and stable cratons. The current stat of knowledge is indicative that Moho depths maps seem to have some degree of correlated with the tectonic scenarios. Receiver function imaging provides some evidence for this proposed correlation.

The increase in lateral resolution of CMP data due to the increase in the number of channels in multichannel acquisition systems and, the advancement of processing algorithms have revealed geometric relationships between the Moho and the surrounding reflections of the lower crust and upper mantle Dipping events discordant with the sub-horizontal Moho have been resolved as well as truncation relationships in other sections. Dipping structures with cross-cutting relationships with a sub-horizontal Moho are visible, for example: in the Precambrian of northern Europe (BABEL transects, Fig. 10); beneath the Caledonides in northern Scotland (GRID, DRUM lines, Fig. 7 among others); under the Variscan CIZ of the Iberia Peninsula (ALCUDIA, transect, Fig. 6); in the western Slave Province along SNORCLE line 1 Fig. 12). Thus, dipping reflections can truncate/interfere with the Moho independently of the geology, and age of the surface terranes. There appears to be little correspondence between the surface geology and/or age of the outcrops with the Moho geometry and structure.

While the RF images provide a relatively well resolve depth map of the Moho boundary, hints on the internal structure and nature can only be obtained from the controlled source refraction/wide-angle and from CMP data, in particular, because they feature higher resolution that RF. For an assessment of the nature of the Moho boundary CMP data is an asset. Developing on Hammer and Clowes (1997); Cook (2002); Eaton (2006); Cook et al. (2010) and taking the Moho image provided by the highest resolution CMP data alone, in general, the reflection character of the Moho can be described as:

- A non-existing Moho, transparent

- Marked by a transition zone from relatively highly reflective crust to a less reflective or transparent upper mantel

- It features a series of smoothly dipping reflection events that coalesce, asymptotically and combine into a horizontal feature 
- Marked by a relatively thin band of horizontal and laterally continuous reflection segments

The relationship of the considered Moho with the reflection fabric in the neighborhood may need to be taken into account as it can reveal further constraints on the nature of the structure and characteristics of the Moho boundary. In this terms, the reflection fabrics around the Moho can be intersecting the Moho transition zone or, they can be smoothly dipping events that coalesce, and combine asymptotically with the horizontal seismic reflection fabric of the Moho.

In general in CMP Moho changes its character laterally so that along the same transect it can present several of the descriptions above. Also this descriptions/categories are not uniquely correlated with the surface geology. For example along active organic belts as the Pyrenees, and Alps, the Moho character changes laterally, for one category to another. This different categories are a result of the different scattering fields (Levander and Holliger 1992). This is the relationship between the wavelength of the acoustic energy used to illuminate the structure and the size of the heterogeneities, the vertical and horizontal correlation lengths.

\subsection{Non-existing Moho, Transparent}

CMP images in some cases reveal diffuse reflectivity in the crust that slowly fades, in this cases there is a difficulty to place the crust mantle transition. It can also happen that the CMP method is not able to obtain a response from the Moho. If the lower crust and upper mantle are both non reflective, no reflection Moho can be defined. The Moho however, has been in most cases traced by using the RF images see for example the case of the Himalayas (Fig. 15). Or can be identified by using wide-angle acquisitions. Fan shot records by Hirn et al. (1984) were able to trace the Moho beneath the Tibet. Another example of a transparent Moho is the image provided by the Urals transect at the location labeled Central Uralian zone, (Fig. 8). Underneath this area and the neighbouring Magnitogorsk Volcanic zone (between CDP 11000-13000) the Moho can not be identified by the CMP data while it is well imaged by the PmP of the wide-angle shot records (Fig. $9)$.

Disregarding source acquisition and processing parameters a non reflective Moho at normal incidence (CMP) is, most probably, an indication of a thick crust-mantle transition zone where the physical parameters (impedance 
field) changes slowly from values typical for the crust to values that are characteristic of the mantle. A gradient zone would be a model that would provide the appropriate CMP response. RF and wide-angle data would be sensitive to this type of structure. Within such a transition zone heterogeneities can not be rulled out, however, they would correspond to a second order variations in the impedance field $(\mathrm{Vp}, \mathrm{Vs}, \rho)$. These heterogeneity field should be characterized by correlation length smaller in size than dominant Fresnel zone of the illuminating acoustic energy. Perhaps, this seismic image could be consistent with a progressing metamorphic front that could take place after a major tectonic orogenic event, as part of the process of re-equilibration of the crust. As a result of a relatively fast tectonic crustal thickening due to a continental orogenesis

\subsection{Marked by a transition zone from highly reflective crust to a less reflec- tive or transparent upper mantel}

In a large number of deep CMP sections the Moho is identified by a change in the reflectivity a relatively sharp decrease in reflectivity. This is the case of the definition of the Moho in some of the BABEL transects (BABEL Working Group 1993a, b). And some transects across the Archean terranes of Canada (Cook 2002; Eaton 2006) and Australia (Goleby et al. 1990; Wright et al. 1990). The interpretation of this type of seismic signature suggests that the Moho transition zone is characterized by well defined heterogeneities. These heterogeneities should feature correlation lengths that are on the order of the dominant Fresnell zone of the illuminating signal (Levander and Holliger 1992). This should generate a diffracted wave field which would generate larger events at far offsets (wide-angle). This far offset events are a result of the constructive interference of far offset diffractions. Processes which can results in an image with this characteristics need to involve the reduction of the contrasts in physical properties and limit the lateral continuity of the internal structure of the transition itself. The later can be related to a decreases in the lateral correlation length if a stochastic velocity and density distribution are considered (Levander and Holliger 1992).

This seismic signature reveals the different heterogeneity patterns of the crust and mantle and could be consistent with stable continental areas where there is tectonic activity is very reduced. In this case the seismic signature only reflects the differences of the compositional heterogeneities of the crust and the Mantle beneath. The change from a reflective lower crust to a less reflective or transparent upper mantle also could be due to scale-length 
changes (Holliger and Levander 1992; Holliger et al. 1992; Levander and Holliger 1992; Holliger et al. 1993; Tittgemeyer et al. 1996, 1999; Ryberg et al. 2000).

\subsection{It features seismic reflection events intersecting the Moho}

Images as the obtained by the DRUM, GRID lines under the Caledonides in northern Scotland (Fig. 7), the structure image in northern Canada by SNORCLE project (Fig. 12), i beneath the Archean Crust in the superior Province (Calvert and Ludden 1999), the upper mantle dipping events imaged by the BABEL project (BABEL Working Group 1990, 1993a, b) most probably reveal the existence of structures which have penetrated the Upper mantle. The origin of which can be to a certain degree uncertain. Some interpretations associate them to be the result of previous major tectonic events and are remnants of the tectonic activity.

This dipping structures that intersect the Moho and, the Moho it self need to be the result of first order variations in the impedance field. A model characterized by a first order impedance field that would reveal the main orientation of the structures and, probably a second order variation in the impedance field superimposed on the former would account for the observed reflectivity signature. In most cases it has been suggested that represent relic structures which have not been assimilated by the mantle yet.

\subsection{It features a series of smoothly dipping reflection events that coalesce, asymptotically and combine into a horizontal feature}

A good example of this features is in Cook et al. (1992). In Europe the Moho beneath the South Portuguesse Zone in the IBERSEIS transect (Simancas et al. 2003) provide an example of inclined reflections within the lower crust that asymptotically combine/coalesce with the interpreted horizontal Moho (Fig. 5), at approximately cdp 2000 and 300). The wide-angle reflection of the Moho beneath this area is a relatively sharp and well defined feature (Fig. 5).

As in the previous case in order to reproduce such features a first order variation in the physical properties that describe the model would result in the observed seismic signature. A boundinage structure would be able to reproduce the observations (Reston 1988). Shear zone at the base of the crust will appear smoothly combining with Moho reflection. Undulating shear-zone could be assimilated to an undulating first order variation in the 
velocity field. The Moho in this type of images most probably is consistent with a relatively large degree of horizontal tectonic activity.

\subsection{Marked by a relatively thin band of horizontal and laterally continuous reflection segments}

Synthetic seismic wave-field modelling studies has revealed that thinly laminated structures consisting of first order variations in the seismic velocity field with horizontal correlation lengths comparable or larger than $\lambda$, result in relatively high amplitude and laterally continuous reflection fabrics.

Relative high amplitude reflection and laterally continuous reflection event for the Moho requires a laterally continuous structure, or at least with a laterally continuous feature structured with lenses or heterogeneities characterized by a lateral correlation length that is on the order or larger than the Fresnel zone. If the reflected waveform features a short wavelet lacking a coda, the reflecting structure is most probably consisting of a relatively thin layered sequence, with relatively large contrast in impedance.

A prominent and horizontal Moho is very well defined for the case of the Basin and Range as described by (Klemperer et al. 1986). Wide-angle records sections of an equivalent are are the ones recorded by the PASSCAL experiment (Carbonell and Smithson 1991). The shot records in this data set reveal a very prominent and laterally continuous Moho reflection with exceptionally high amplitude reflectivity. 3D finite difference modelling of the PASSCAL wide-angle seismic data suggested that observed differences in the perpendicular directions could be explained by an anisotropic structure. This could be modelled as a boudinage structure stretched in the E-W directions (Carbonell and Smithson 1991). This is tectonic lenses elongated in the stretching direction these lenses are characterized by a long, east-west axis (approximately the length of a Fresnel zone) and a short, north-south axis (approximately 0.25 of the length of a Fresnel zone). Hamilton (1987) suggested that such tectonic lenses could easily accommodate extension. A model consisting of boudins delineated by a network of anastomosing shear zones (Reston 1988) or lenses that simply "float" in a matrix that can undergo plastic deformation. During extension these lenses are pulled apart, and the stretching is taken up dominantly by simple shear within the zones separating the boudins. This can effectively explain the anisotropy. Furthermore boudins will flatten with increasing depth and temperature.

Also the intrusion as horizontal sills of mafic and ultramafic rocks at the base of the crust and within the lower crust (underplating) can generate 
laminated structures. The emplacement of this igneous sills can take place episodically during extensional tectonic events which stretch the crust. This process will generate a distinctive structure which will indeed be characterized by high densities and velocities that will result in a sequence of high impedance contrast which will generate a high amplitude and laterally continuous reflection event. Furthermore, this layer structure, a stack of mafic sills are imaged as layered reflection sequence.

\section{Seismic and the Petrologic Moho}

The coincidence between the seismic and the petrologic Moho's has been a topic which has motivated large amount of discussion. This overview would not be complete without at least mentioning this point which will be discussed within this volume.

The definition of the Moho is based on an observation derived from seismic data and thus is mainly a seismic definition. The Moho as it has been stated is the transition zone where the average seismic velocity of $\mathrm{P}$ waves changes to values approaching $8.0 \mathrm{~km} / \mathrm{s}$. From a seismological point of view, for this change in physical properties to happen, a change in the lithologies of the rocks (through which the seismic energy has traveled) needs to take place. On first approximation these changes in petrology and seismic velocity should coincide. However, in detail this simple correlation is a very complex association. The seismic definition of the Moho is based in a change in the average velocities. This average value has to be understood as a weighted average. The weights are a function of the frequency content of the seismic waves and the scale of the geological structures. This introduces a large amount of complexity into the association of the seismic and petrologic Moho's. Griffin and Reilly (1987); Hynes and Snyder (1995) have discussed the issue of the non-coincidence of the lithologic and seismic Moho's from the petrologic point of view based on xenolith evidence. In this case the temperature regime has an important role in determining the depth position of the petrologic Moho in the crustal column. Griffin and Reilly (1987) argue that the Moho in the lithologic column is determined by the temperature regime.

Active tectonics and the temperature regime will modify de lower crust and/or the upper mantle. The scale and the intensity of the processes will define the extension and location of the Moho. This processes will act on the rocks overprinting a series of additional factors which will affect the seismic signature, for example: rock fabrics and anisotropy. In this sense the 
seismic and the petrologic Moho's could be placed at different levels. Synthetic seismic data from the petrophysical column from the surface outcrop of deep crustal and upper mantle rocks of the Cabo Ortegal (North Western Iberia) area (Brown et al. 2009) suggest hat the petrologic Moho would be located deeper than the seismic Moho. In this case the contact between the Gneiss and an Eclogitic unit. would be considered as the seismic Moho. The petrologic the Moho, the transition from granulites to ultramafic rock considered to be mantle lithologies would be located slightly deeper in the column. In other outcrops the seismic Moho has been considered to correspond to the lithological contact between gabbros and rock with ultramafic compositions (harzburgites), and the petrologic Moho has been correlated with the deeper structures/fabrics and, lithological contrasts within the ultramafics (eg. peridoties, dunites, etc).

\section{Summary and Conclusion}

Distinct images of the Moho have been resolved by the different types of seismic data. The multi-seismic (passive and controlled source) data feature different resolutions and provide a complementary view on this important structure. RF provide a low resolution image placing constraints on the depth, topography of this boundary. Refraction/wide-angle controlled source data constrain the physical properties, and depth. CMP feature the highest resolution and reveal the internal structure of this boundary. The

seismic data of the different types has sampled a relatively complete sweep of key geologic structures and has placed important constraint on the depth, geometry and nature of the Moho. This has resulted in new ideas on the growth and evolution of the continental crust. These seismic images obtained up to date correspond to, most probably, picture, snapshot in time. Thus the image that is obtained of the crust-mantle transition through seismic methods needs to be interpreted as a result of the tectonics, that the lithosphere in a particular area has gone through. The deep crust and Moho are most probably being continuously altered and reset by the influence of the mantle. Tectonics is the surface expression of the mantle-crust interaction. Therefore the Moho is a dynamic feature (in geologic time scale) and is continuously being modified. The images that we obtain are just snapshots of the Moho at the present time but reflect the results of many possible processes involved in its development over geological timescales. The Moho features a relatively simple definition (the interface where $\mathrm{P}$ seismic wave 
velocity increase from $5.60 \mathrm{~km} / \mathrm{s}$ to values larger than $7.75 \mathrm{~km} / \mathrm{s}$ ) In detail it has a variety of signatures at different resolution scales. This prevents a single and universally applicable interpretation. The origin and nature and its role in crustal evolution are perhaps best determined by careful analyses of its structural details, which are complex and varied. The sharpness of this transition zone can, most probably, be interpreted as a tectonic overprint and its broadness/diffuseness could be associated to a long lasting and distributed metamorphic processes.

\section{Acknowledgements}

This contribution was developed while R. Carbonell was at the Earthquake Research Institute of the Tokyo University. R. C. acknowledges funding from the Spanish Ministry of Science and Innovation (grants: CSD200600041; CGL2011-24101) and the Generalitat de Catalunya (grant: 2009SGR006). We thank R Clowes and $\mathrm{H}$. Thybo for their constructive criticism that improved the manuscript. 


\section{References}

Abbott, D.H., Drury, R., Mooney, W.D., 1997. Continents as lithological icebergs: The importance of buoyant lithospheric roots. Earth and Planetary Science Letters 149, 15-27.

Aki, K., Richards, P., 1980. Quantitative Seismology: Theory and Methods. W.H Freeman.

Alinaghi, A., Bock, G., Kind, R., Hanka, W., Wylegalla, K., Groups, S.W., 2003. Receiver function analysis of the crust and upper mantle from the North German Basin to the Archaean Baltic Shield. Geophysical Journal International 155, 641-652.

Allegre, C.J., Courtillot, V., Tapponnier, P., Hirn, A., Mattauer, M., Coulon, C., Jaeger, J., Achache, J., Scharer, U., Marcoux, J., Burg, J.P., Girardeau, J., Armijo, R., Gariepy, C., Gopel, C., Tindong, L., Xuchang, X., Chenfa, C., Guangqin, L., Baoyu, L., Jiwen, T., Naiwen, W., Guoming, C., Tonglin, H., Xibin, W., Wanming, D., Huaibin, S., Yougong, C., Ji, Z., Hongrong, Q., Peisheng, B., Songchan, W., Bixiang, W., Yaoxiu, Z., Xu, R., 1984. Structure and Evolution of Himalaya-Tibet orogenic belt. Nature 307, 17-22.

Alsdorf, D., Makovsky, Y., Zhao, W., Brown, L.D., Nelson, K.D., Klemperer, S., Hauck, M., Ross, a., Cogan, M., Clark, M., Che, J., Kuo, J., 1998. INDEPTH (International Deep Profiling of Tibet and the Himalaya) multichannel seismic reflection data: Description and availability. Journal of Geophysical Research 103, 26993. doi:10.1029/98JB01078.

Asencio, E., Knapp, J., Owens, T., Helffrich, G., 2003. Mapping fine-scale heterogeneities within the continental mantle lithosphere beneath Scotland : Combining active- and passive-source seismology. Geolology 31, 477-480.

BABEL Working Group, 1990. Evidence for Early Proterzoic plate tectonics from seismic reflection profiles in the Baltic Shield. Nature 348, 34-38.

BABEL Working Group, 1993a. Integrated seismic studies of the Baltic shield using data in the Gulf of Bothnia region. Geophysical Journal International 112, 305-324. 
BABEL Working Group, 1993b. Deep seismic reflection / refraction interpretation of crustal structure along BABEL profiles A and B in the southern Baltic Sea. Geophysical Journal International 112, 325-343.

Balling, N., 2000. Deep seismic reflection evidence for ancient subduction and collision zones within the continental lithosphere of northwestern Europe. Tectonophysics 329, 269-300.

Beloussov, V., Vol'vovski, B., Vol'vovski, I., Ryabo, V., 1962. Experimental investigation of the recording of deep reflected waves. Bull. (Izvestiya), Acad. Sci., U.S.S.R., Geophys . Ser., English Translation 8, 6652-669.

Berzin, R., Knapp, J.H., Hismatulin, T., Yunusov, N., Lipilin, A., 1996. Orogenic Evolution of the Ural Mountains : Results from an Integrated Seismic Experiment. Science 274.

Bois, C. and ECORS Scientific Party, 1990. Major geodynamic processes studied from the ECORS deep seismic profiles in France and adjacent areas. Tectonophysics 173, 297-410.

Bostock, M.G., Rondenay, S., 1999. Migration of scattered teleseismic body waves. Geophysical Journal International 137, 732-746.

Brewer, J.A., Smythe, D.K., 1984. MOIST and the continuity of crustal reflector geometry along the Caledonian-Appalachian orogen. Journal of the Geological Society 141, 105-120. doi:10.1144/gsjgs.141.1.0105.

Brown, D., Llana-Funez, S., Carbonell, R., Alvarez-Marron, J., Marti, D., Salisbury, M., 2009. Laboratory measurements of P-wave and S-wave velocities across a surface analog of the continental crust-mantle boundary: Cabo Ortegal, Spain. Earth and Planetary Science Letters 285, 27-38. doi:10.1016/j.epsl.2009.05.032.

Calvert, A.J., Cruden, A.R., Hynes, A., 2004. Seismic evidence for preservation of the Archean Uchi granite - greenstone belt by crustal-scale extension. Tectonophysics 388, 135-143. doi:10.1016/j.tecto.2004.07.043.

Calvert, A.J., Ludden, J.N., 1999. Archean continental assembly in the southeastern superior province of canada. Tectonics 18, 412-429. 
Carbonell, R., Gallart, J., Diaz, J., Kashubin, S., Mechie, J., Wenzel, F., Knapp, J., Abstract, A., 2000. Seismic wide-angle constraints on the crust of the Southern Urals. Journal of Geophysical Research 105, 1375513777.

Carbonell, R., Gallart, J., Perez-Estaun, A., 2002. Modelling and imaging the Moho transition : the case of the southern Urals. Geophysical Journal International , 134-148.

Carbonell, R., Lecerf, D., Itzin, M., Gallart, J., Brown, D., 1998. Mapping the Moho beneath the southern with wide-angle reflections. Geophysical Research Letters 25, 4229-4232.

Carbonell, R., Pérez-Estaún, A., Gallart, J., Diaz, J., Kashubin, S., Mechie, J., Stadtlander, R., Schulze, A., Knapp, J.H., Morozov, A., 1996. Crustal root beneath the urals: Wide-angle seismic evidence. Science 274, 222224.

Carbonell, R., Simancas, F., Juhlin, C., Pous, J., Pérez-Estaún, A., Gonzalez-Lodeiro, F., nozG., M., Heise, W., P., A., 2004. Geophysical evidence of a mantle derived intrusion in SW Iberia. Geophysical Research Letters 31, 2-5. doi:10.1029/2004GL019684.

Carbonell, R., Smithson, S.B., 1991. Large-scale anisotropy within the crust in the Basin and Range province. Geology 19, 698.

Cassinis, R., 2006. Reviewing pre-TRANSALP DSS models. Tectonophysics $414,79-86$.

Castellarin, A., Nicolich, R., Fantoni, R., Cantelli, L., Sella, M., Selli, L., 2006. Structure of the lithosphere beneath the Eastern Alps (southern sector of the TRANSALP transect). Tectonophysics 414, 259-282. doi:10.1016/j.tecto.2005.10.013.

Chevrot, S., van der Hilst, R.D., 2000. The Poisson ratio of the Australian crust: geological and geophysical implications. Earth and Planetary Science Letters 183, 121-132. doi:10.1016/S0012-821X(00)00264-8.

Choukroune, P., Roure, F., Pinet, B., ECORS, P., 1990. Main results of the ECORS Pyrenees profile. Tectonophysics 173, 411-423. 
Choukroune, P., Team, E.W., 1989. The ECORS Pyrenean Deep Seismic Profile Reflection data and the overall structure of an orogenic belt. Tectonics 8, 23-39.

Christensen, N., Mooney, W., 1995. Seismic Velocity Structure Composition of the Continental Crust (1).pdf. Journal of Geophysical Research 100, 9761-9788.

Clowes, R., Gens-Lenartowicz, E., Demartin, M., Saxov, S., 1987. Lithospheric structure in southern Swedenresults from FENNOLORA. Tectonophysics 142, 1-14. doi:10.1016/0040-1951(87)90291-5.

Clowes, R.M., Burianyk, M.J., Gorman, A.R., Kanasewich, E.R., 2002. Crustal velocity structure from SAREX, the Southern Alberta Refraction Experiment. Canadian Journal of Earth Sciences 39, 351-373. doi:10.1139/e01-070.

Clowes, R.M., Hammer, P.T., Fernández-Viejo, G., Welford, J.K., 2005. Lithospheric structure in northwestern Canada from Lithoprobe seismic refraction and related studies: a synthesis. Canadian Journal of Earth Sciences 42, 1277-1293. doi:10.1139/e04-069.

Clowes, R.M., Kanasewich, E., Cumming, G., 1968. Deep crustal seismic reflections at near-vertical incidence. Geophysics 33, 441-551.

Collier, J.S., Buhl, P., Torne, M., Watts, A.B., 1994. Moho and lower crustal reflectivity beneath a young rift basin : results from a two-ship, wideaperture seismic-reflection experiment in the Valencia Trough ( western Mediterranean ). Geophysical Journal International 118, 159-180.

Cook, F., Varsek, J., Clowes, R., Kanasewich, E., Spencer, C., Parrish, R., Brown, R., Carr, S., Johnson, B., Price, R., 1992. Lithoprobe crustal reflection cross section of the southern Canadian Cordillera, I: Foreland thrust and fold belt to Fraser River fault. Tectonics 11, 12-35.

Cook, F.A., 2002. Fine structure of the continental reflection Moho. Geological Society of America Bulletin , 64-79doi:10.1130/0016$7606(2002) 114 ; 0064$.

Cook, F.a., Clowes, R., Snyder, D., van der Velden, A.J., Hall, K., Erdmer, P., Evenchick, C., 2004. Precambrian crust beneath the Mesozoic 
northern Canadian Cordillera discovered by Lithoprobe seismic reflection profiling. Tectonics 23, 1-28. doi:10.1029/2002TC001412.

Cook, F.A., Velden, A.J.V.D., Hall, K., Roberts, B., 1998. Tectonic delamination and subcrustal imbrication of the Precambrian lithosphere in northwestern Canada mapped by LITHOPROBE. Geology 26, 839-842.

Cook, F.A., White, D.J., Jones, A.G., Eaton, D., Hall, J., Clowes, R.M., 2010. How the crust meets the mantle : Lithoprobe perspectives on the Mohorovic discontinuity and crust - mantle transition. Canadian Journal of Earth Sciences 351, 315-351. doi:10.1139/E09-076.

Czuba, W., Grad, M., Piotr, S., Guterch, A., Gaczyn, E., 2002. Threedimensional seismic modelling of crustal structure in the TESZ region based on POLONAISE'97 data. Tectonophysics 360, 169-185.

Darbyshire, F.A., Eaton, D.W., Frederiksen, A.W., Ertolahti, L., 2007. New insights into the lithosphere beneath the Superior Province from Rayleigh wave dispersion and receiver function analysis. Geophysical Journal International 169, 1043-1068. doi:10.1111/j.1365-246X.2006.03259.x.

Deichmann, N., Ansorge, J., Mueller, S., 1986. Crustal structure of the Southern Alps beneath the intersection with the European Geotraverse. Tectonophysics 126, 57-83. doi:10.1016/0040-1951(86)90220-9.

Díaz, J., Gallart, J., 2009. Crustal structure beneath the Iberian Peninsula and surrounding waters: A new compilation of deep seismic sounding results. Physics of the Earth and Planetary Interiors 173, 181-190. doi:10.1016/j.pepi.2008.11.008.

Díaz, J., Pedreira, D., Ruiz, M., Pulgar, J., Gallart, J., 2012. Mapping the indentation between the Iberian and Eurasian plates beneath the Western Pyrenees/Eastern Cantabrian Mountains from receiver function analysis. Tectonophysics 570-571, 114-122. doi:10.1016/j.tecto.2012.07.005.

Dix, C., 1965. Reflection seismic crustal studies. Geophysics 30, 1068-1084.

Dohr, G., 1957. Ein beitrag der reflexionsseismik zur erforschung des tieferen untergrundes. Geologische Rundschau 46, 17-26. 
Druzhinin, V., Kashubin, S., Kashubina, T., Kolmogorova, V., Parygin, G., a.V. Rybalka, a.M. Tiunova, 1997. The main features of the interface between the crust and the upper mantle in the Middle Urals (in the vicinity of the deep drillhole SG-4). Tectonophysics 269, 259-267. doi:10.1016/S0040-1951(96)00163-1.

Dueker, K.G., Sheehan, A.F., 1997. Mantle discontinuity structure from midpoint stacks Yellowstone hotspot track ratio our Pds times B , Borah $\mathrm{pP}$ and phases Yellowstone hotspot track ; $\mathrm{H}$, near the $\mathrm{P}$ wave . The ray. Journal of Geophysical Research 102, 8313-8327.

Eaton, D., Hope, J., 2003. Structure of the crust and upper mantle of the Great Slave Lake shear zone, northwestern Canada, from Teleseismic analysis and gravity modelling. Canadian Journal of Earth Sciences 40, 12031218. doi:10.1139/e03038.

Eaton, D.W., 2006. Multi-genetic origin of the continental Moho: insights from Lithoprobe. Terra Nova 18, 34-43. doi:10.1111/j.13653121.2005.00657.x.

Echtler, H., M., S., F., S., Krawczyk, C., Suleimanov, A., Spiridonov, V., Knapp, J., Menshikov, Y., Alvarez-Marron, J., Yunusov, N., 1996. Preserved Collisional Crustal Structure of the Southern Urals Revealed by Vibroseis Profiling. Science 274, 224-226.

Flecha, I., Palomeras, I., Carbonell, R., Simancas, F., Ayarza, P., Matas, J., González-Lodeiro, F., Pérez-Estaún, a., 2009. Seismic imaging and modelling of the lithosphere of SW-Iberia. Tectonophysics 472, 148-157. doi:10.1016/j.tecto.2008.05.033.

Franke, B.W., Bortfeld, R.K., Brix, M., Drozdzewski, G., Thonker, M., Weber, K., Wiesni, M.G.R., Wong, H.K., 2000. Crustal structure of the Rhenish Massif : results of deep seismic reflection lines DEKORP 2North and 2-North-Q. Geologische Rundschau , 523-566.

Frederiksen, A.W., Revenaugh, J., 2004. Lithospheric imaging via teleseismic scattering tomography. Geophysical Journal International 159, 978-990. doi:10.1111/j.1365-246X.2004.02414.x.

Geissler, W.H., Kämpf, H., Skácelová, Z., Plomerová, J., Babuška, V., Kind, R., 2012. Lithosphere structure of the NE Bohemian Massif (Sudetes) 
A teleseismic receiver function study. Tectonophysics 564-565, 12-37. doi:10.1016/j.tecto.2012.05.005.

Giese, P., 2005. The Moho Discontinuity, in: Encyclopedia of Geology, R.C. Selly L.R.M. Cocks and I.R. Plimier eds.Vol. 3, pp. 645-659.

Goleby, B., Blewett, R., Korsch, R., Champion, D., Cassidy, K., Jones, L., Groenewald, P., Henson, P., 2004. Deep seismic reflection profiling in the Archaean northeastern Yilgarn Craton, Western Australia: implications for crustal architecture and mineral potential. Tectonophysics 388, 119133. doi:10.1016/j.tecto.2004.04.032.

Goleby, B., Kennett, B., Wright, C., Shaw, R., Lambeck, K., 1990. Seismic reflection profiling in the Proterozoic Arunta Block, central Australia: processing for testing models of tectonic evolution. Tectonophysics 173, 257-268. doi:10.1016/0040-1951(90)90222-T.

Goleby, B.R., Drummond, B.J., Rattenbury, M.S., Williams, P.R., 1997. Crustal structure of granite-greenstone terranes in the Eastern Goldfields , Yilgarn Craton, as revealed by seismic reflection profiling. Precambrian Research 83, 43-56.

Grad, M., Gryn', D., Guterch, a., Janik, T., Keller, R., Lang, R., Lyngsie, S., Omelchenko, V., Starostenko, V., Stephenson, R., Stovba, S., Thybo, H., Tolkunov, a., 2003. DOBREfraction'99 Velocity model of the crust and upper mantle beneath the Donbas Foldbelt (East Ukraine). Tectonophysics 371, 81-110. doi:10.1016/S0040-1951(03)00211-7.

Grad, M., Guterch, A., Keller, G.R., Janik, T., Hegeds, E., Vozár, J., Ślczka, A., Tiira, T., Yliniemi, J., 2006. Lithospheric structure beneath transCarpathian transect from Precambrian platform to Pannonian basin: CELEBRATION 2000 seismic profile CEL05. Journal of Geophysical Research 111, 1-23. doi:10.1029/2005JB003647.

Grad, M., Guterch, A., Mazur, S., Keller, G.R., Špičák, A., Hrubcová, P., Geissler, W.H., 2008. Lithospheric structure of the Bohemian Massif and adjacent Variscan belt in central Europe based on profile S01 from the SUDETES 2003 experiment. Journal of Geophysical Research 113, 1-25. doi:10.1029/2007JB005497. 
Grad, M., Keller, G.R., Thybo, H., Guterch, A., 2002. Lower lithospheric structure beneath the Trans-European Suture Zone from POLONAISE 97 seismic profiles. Tectonophysics 360, 153-168.

Grad, M., Tiira, T., 2009. The Moho depth map of the European Plate. Geophysical Journal International 176, 279-292. doi:10.1111/j.1365246X.2008.03919.x.

Gregersen, S., Voss, P., 2002. Summary of project TOR: delineation of a stepwise, sharp, deep lithosphere transition across GermanyDenmarkSweden. Tectonophysics 360, 61-73. doi:10.1016/S0040-1951(02)00347-5.

Griffin, W.L., Reilly, S.Y.O., 1987. Is the continental Moho the crust-mantle boundary? Geology 15, 241-244.

Guterch, A., Grad, M., Keller, G., Posgay, K., Vozár, J., Pičák, A., E., B., Hajnal, Z., Thybo, H., O., S., Team, C..E., 2003a. CELEBRATION 2000 Seismic Experiment. Studia Geophysica et Geodaetica 47, 659-669.

Guterch, A., Grad, M., Pičák, A., Brückl, E., Hegedüs, E., Keller, G., Thybo, H., 2000, C., 2002, A., Groups, S..W., 2003b. An Overview of Recent Seismic Refraction Experiments. Studia Geophysica et Geodaetica 47, 651-657.

Guterch, A., Grad, M., Thybo, H., Keller, G., 1999. POLONAISE '97 an international seismic experiment between Precambrian and Variscan Europe in Poland. Tectonophysics 314, 101-121. doi:10.1016/S00401951(99)00239-5.

Hale, L.D., Thompson, G.A., 1982. Mohorovičićic Discontinuity. Journal of Geophysical Research 87, 4625-4635.

Hall, J., Marillier, F., Dehler, S., 1998. Geophysical studies of the structure of the Appalachian orogen in the Atlantic borderlands of Canada. . Canadian Journal of Earth Sciences 35, 1205-1221. doi:10.1139/cjes-3511-1205.

Hamilton, W., 1987. Crustal extension in the basin and range province, southwestern united states, in: Continental extension tectonics: Geological Society of London Special Publication 28, Coward, M.P. and Dewey, J.F. and Handcock, P.L. (editors), pp. 155-176. 
Hammer, P., Clowes, R., 1997. Moho reflectivity patterns a comparison of Canadian lithoprobe transects. Tectonophysics 269, 179-198. doi:10.1016/S0040-1951(96)00164-3.

Hirn, A., Jiang, M., Sapin, M., Diaz, J., Nercessian, A., Lu, Q.T., Lepine, J.C., Shi, D.N., Sachpazi, M., Pandey, M.R., Gallart, J., 1995. Seismic anisotropy as an indicator of mantle flow beneath the Himalayas and Tibet. Nature 375, 571-574.

Hirn, A., Lepine, J., Jobert, G., Sapin, M., Wittlinger, G., Zhong-Xin, X., 1984. Crustal Structure and Variability of Himalayan border of Tibet. Nature 307, 23-25.

Hole, J.A., 1992. Nonlinear High-Resolution Three-Dimensional Seismic Travel Time Tomography. Journal of Geophysical Research 97, 65536562 .

Hole, J.A., Zelt, C.A., 1995. 3D finite-difference reflection traveltimes. Geophysical Journal - Royal Astronomical Society 121, 427-434.

Holliger, K., Carbonell, R., Levander, A.R., 1992. Sensitivity of the lateral correlation function in deep seismic reflection data. Geophysical Research Letters 19, 2263-2266.

Holliger, K., Kemperer, S.L., 1989. A comparison of the Moho interpreted from gravity data and from deep seismic reflection data in the northern North Sea. Geophysical Journal 97, 247-258.

Holliger, K., Levander, A., 1992. A Stochastic view of Lower Crustal Fabric based on evidence from the Ivrea Zone. Geophysical Research Lett 19, 1153-1156. doi:10.1029/92GL00919.

Holliger, K., Levander, A.R., Gof, J.A., Goff, J.A., 1993. Stochastic Modeling of the Reflective Lower Crust: Petrophysical and Geological Evidence From the Ivera Zone (Northern Italy). Journal of Geophysical Research 98, PP. 11,967-11,980.

Hughes, S., Hall, J., Luetgert, J.J.H., 1994. The seismic velocity structure of the Newfoundland Appalachian orogen. Journal of Geophysical Research 99, 13633-13653. 
Hynes, A., Snyder, D.B., 1995. Deep-crustal mineral assemblages and potential for crustal rocks below the Moho in the Scottish Caledonides. Geophysical Journal International 123, 323-339. doi:10.1111/j.1365246X.1995.tb06857.x.

Janik, T., Yliniemi, J., Grad, M., Thybo, H., Tiira, T., 2002. Crustal structure across the TESZ along POLONAISE'97 seismic profile P2 in NW Poland. Tectonophysics 360, 129-152. doi:10.1016/S0040-1951(02)003530.

Jarchow, C., Thompson, G., 1989. The Nature of the Mohorovičićic Discontinuity. Annual Review of Earth and Planetary Sciences 17, 475-506. doi:10.1146/annurev.ea.17.050189.002355.

Jensen, S.L., Janik, T., Thybo, H., Profile, P., Working, P., 1999. Seismic structure of the Palaeozoic Platform along POLONAISE'97 profile P1 in northwestern Poland. Tectonophysics 314, 123-143.

Jensen, S.L., Thybo, H., Polonaise, T., Group, W., 2002. Moho topography and lower crustal wide-angle reflectivity around the TESZ in southern Scandinavia and northeastern Europe. Tectonophysics 360, 187-213.

Jones, A., Ferguson, J., 2001. The Electric Moho. Nature 409, 331-333.

Juhlin, C., Friberg, M., Echtler, H.P., Hismatulin, T., Rybalka, A., Green, A., Ansorge, J., 1998. Crustal structure of the Middle Urals: Results from the (ESRU) Europrobe seismic reflection profiling in the Urals experiments. Tectonics 17, 710-725.

Juhlin, C., Knapp, J., Kashubin, S., Bliznetsov, M., 1996. Crustal evolution of the Middle Urals based on seismic reflection and refraction data. Tectonophysics 264, 21-34.

Kay, I., Sol, S., Kendall, J.m.J., Thomson, C., White, D., Asudeh, I., Roberts, B., Francis, D., 1999. Shear wave splitting observations in the Archean Craton of western Superior. Geophysical Research Letters 26, 2669. doi:10.1029/1999GL010493.

Kind, R., Yuan, X., 2010. Geophysics. Seismic images of the biggest crash on Earth. Science (New York, N.Y.) 329, 1479-80. doi:10.1126/science.1191620. 
Klemperer, S.L., Hauge, T.a., Hauser, E.C., Oliver, J.E., Potter, C.J., 1986. The Moho in the northern Basin and Range province, Nevada, along the COCORP 40N seismic-reflection transect. Geological Society of America Bulletin 97, 603. doi:10.1130/00167606(1986)97;603:TMITNB ¿2.0.CO;2.

Knapp, J.H., Steer, D.N., Brown, L.D., Berzin, R., Suleimanov, A., Stiller, M., Luschen, E., Brown, D.L., Bulgakov, R., Kashubin, S.N., Rybalka, A.V., 1996. Lithosphere-Scale Seismic Image of the Southern Urals from Explosion-Source Reflection Profiling. Science 274, 226-228.

Kosarev, G., 1999. Seismic Evidence for a Detached Indian Lithospheric Mantle Beneath Tibet. Science 283, 1306-1309. doi:10.1126/science.283.5406.1306.

Kryza, R., Zalasiewicz, J., 2008. Records of Precambrian-Early Palaeozoic volcanic and sedimentary processes in the Central European Variscides: A review of SHRIMP zircon data from the Kaczawa succession (Sudetes, SW Poland). Tectonophysics 461, 60-71. doi:10.1016/j.tecto.2008.04.003.

Kukkonen, I., Lahtinen, R., 2006. The Finish reflection experiment FIRE 2001-2005. Geol. Survey of Finland, Sp. Paper, 43. Espoo, 247 pp.

Kummerow, J., Kind, R., Oncken, O., Giese, P., Ryberg, T., Wylegalla, K., Scherbaum, F., 2004. A natural and controlled source seismic profile through the eastern alps: Transalp. Earth and Planetary Science Letters 225, 115-129. doi:10.1016/j.epsl.2004.05.040.

Langston, C.A., 1979. Structure Under Mount Rainer, Washington, Infered From Teleseismic Body Waves. Journal of Geophysical Research 84, 4749-4762.

Larkin, P., Levander, A., John, A., 1996. A deterministic and stochastic velocity model for the Salton Trough / Basin and Range transition zone and constraints on magmatism during rifting. Geology 101.

Lemieux, S., Ross, G., Cook, F., 2000. Crustal geometry and tectonic evolution of the Archean crystalline basement beneath the southern Alberta Plains, from new seismic reflection and potential field studies. Canadian Journal of Earth Sciences 37, 1473-1491. 
Levander, A., Hill, N., 1985. P-SV Resonances in Irregular Low/Velocity Surface Layers. Bulletin of the Seismological Society of America 75, 847864.

Levander, A., Holliger, K., 1992. Small-Scale Heterogeneity and LargeScale Velocity Structure. Journal of Geophysical Research 97, 8797-8804. doi:10.1029/92JB00659.

Levander, A., Miller, M.S., 2012. Evolutionary aspects of lithosphere discontinuity structure in the western U.S. Geochemistry Geophysics Geosystems 13, Q0AK07. doi:10.1029/2012GC004056.

Levander, a., Schmandt, B., Miller, M.S., Liu, K., Karlstrom, K.E., Crow, R.S., Lee, C.T.a., Humphreys, E.D., 2011. Continuing Colorado plateau uplift by delamination-style convective lithospheric downwelling. Nature 472, 461-5. doi:10.1038/nature10001.

Liebscher, H., 1962. Reflexionshorizonte der tieferen Erdkruste im bayerischen Alpenvorland, abgeleitet aus Ergebnissen der Reflexionsseismik. Zeitschrift der Geophysik 28, 162-184.

Lüschen, E., Lammerer, B., Gebrande, H., Millahn, K., Nicolich, R., 2004. Orogenic structure of the Eastern Alps, Europe, from TRANSALP deep seismic reflection profiling. Tectonophysics 388, 85102. doi:10.1016/j.tecto.2004.07.024.

Majdanki, M., Grad, M., Guterch, A., 2006. 2-D seismic tomographic and ray tracing modelling of the crustal structure across the Sudetes Mountains basing on SUDETES 2003 experiment data. Tectonophysics 413, 249269. doi:10.1016/j.tecto.2005.10.042.

Malinowski, M., 2009. Structure of the crust/mantle transition beneath the Variscan foreland in SW Poland from coincident wideangle and near-vertical reflection data. Tectonophysics 471, 260-271. doi:10.1016/j.tecto.2009.02.025.

Malinowski, M., Grad, M., Guterch, a., Takács, E., Śliwiski, Z., Antonowicz, L., Iwanowska, E., Keller, G., Hegeds, E., 2007. Effective sub-Zechstein salt imaging using low-frequency seismics - Results of the GRUNDY 2003 experiment across the Variscan front in the Polish Basin. Tectonophysics 439, 89-106. doi:10.1016/j.tecto.2007.03.006. 
Martínez Poyatos, D., Carbonell, R., Palomeras, I., Simancas, J.F., Ayarza, P., Martí, D., Azor, a., Jabaloy, A., González Cuadra, P., Tejero, R., Martín Parra, L.M., Matas, J., González Lodeiro, F., Pérez-Estaún, a., García Lobón, J.L., Mansilla, L., 2012. Imaging the crustal structure of the Central Iberian Zone (Variscan Belt): The ALCUDIA deep seismic reflection transect. Tectonics 31, 1-21. doi:10.1029/2011TC002995.

McBride, J.H., Snyder, D.B., England, R.W., Hobbs, R.W., 1995. Upper mantle reflector structure and origin. Tectonics 14, 1351-1367.

Mechie, J., Prodehl, C., Fuchs, K., 1983. The long-range seismic refraction experiment in the Rhenish Missif., in: K. Fuchs, K. van Gehlen, H. Mllzer, H. Murawski and A. Semmel (Editors), Plateau Uplift. Springer, Berlin,, pp. 260-215.

Meissner, R., 1973. The Moho as a Transition Zone. Surveys in Geophysics 1, 195-216.

Mohorovičićic, A., 1910. Godisnje izvjesce zagrebackog meteoroloskog opservatorija za godinu. Jahrb. Meteorol. Obs. Zagreb 9, Teil 4, Absch. 14 , $1-63$.

Mooney, W., Laske, G., Masters, G., 1998. CRUST 5.1: A global crustal model at 5x5. Journal of Geophysical Research 103, 727-747.

Mooney, W.D., Meissner, R., 1992. Multi-genetic origin of crustal reflectivity : a review of seismic reflection profiling of the continental lower crust and Moho, in: Contitnental Lower Crust, D.M. Fountain, R. Arculus and R.W. Kay, Elsevier Amsterdam, pp. 45-79.

Morgan, R.P.L., Barton, P.J., Warner, M., Morgan, J., Price, C., Jones, K., 2000. Lithospheric structure north of Scotland-I . P-wave modelling, deep reflection profiles and gravity. Geophysical Journal International $142,716-736$.

Morozov, I.B., Smithson, S.B., Chen, J., Hollister, L.S., 2001. Generation of new continental crust and terrane accretion in Southeastern Alaska and Western British Columbia: constraints from P- and Swave wide-angle seismic data (ACCRETE). Tectonophysics 341, 49-67. doi:10.1016/S0040-1951(01)00190-1. 
Nábelek, J., Hetényi, G., Vergne, J., Sapkota, S., Kafle, B., Jiang, M., Su, H., Chen, J., Huang, B.S., 2009. Underplating in the Himalaya-Tibet collision zone revealed by the Hi-CLIMB experiment. Science (New York, N.Y.) $325,1371-4$. doi:10.1126/science.1167719.

Nelson, K., Zhao, W., Brown, L., Kuo, J., Che, J., Liu, X., Klemperer, S., Makovsky, Y., Meissner, R., Mechie, J., Kind, R., Wenzel, F., Ni, J., Nabelek, J., Leshou, C., Tan, H., Wei, W., Jones, A., Booker, J., Unsworth, M., Kidd, W., Hauck, M., Alsdorf, D., Ross, a., Cogan, M., Wu, C., Sandvol, E., Edwards, M., 1996. Partially Molten Middle Crust Beneath Southern Tibet: Synthesis of Project INDEPTH Results. Science (New York, N.Y.) 274, 1684-8.

Nelson, K.D., McBride, J.H., Arnow, J.A., Oliver, J.E., Brown, L.D., Kaufman, S., 1985. New COCORP profiling in the southeastern United States . Part II : Brunswick and east coast magnetic anomalies, opening of the north-central Atlantic Ocean. Geology , 718-721.

Németh, B., Clowes, R.M., Hajnal, Z., 2005. Lithospheric structure of the Trans-Hudson Orogen from seismic refraction - wide-angle reflection studies. Canadian Journal of Earth Sciences 42, 435-456. doi:10.1139/e05-032.

Nicholson, T., Bostock, M., Cassidy, J., 2005. New constraints on subduction zone structure in northern Cascadia. Geophysical Journal International 161, 31-51. doi:10.1111/j.1365-246X.2005.02605.x.

Oliver, J., 1982. Changes at the Crust-Mantle Boundary. Nature 299, 398399.

Oncken, O., 1998. Orogenic mass transfer and reflection seismic patterns evidence from DEKORP sections across the European Variscides (central Germany). Tectonophysics 286, 47-61. doi:10.1016/S00401951(97)00254-0.

O'Reilly, S., Griffin, W.L., Finlayson, D.M., Owen, A.J., Johnstone, D.W., 1994. Moho and Petrologic crust-mantle boundary coincide under southeastern Australia Comment and Reply. Geology 22, 666-668. doi:10.1130/0091-7613(1994)022ز0666. 
Oueity, J., Clowes, R.M., 2010. Nature of the Moho transition in NW Canada from combined near-vertical and wide-angle seismic-reflection studies. Lithosphere 2, 377-396. doi:10.1130/L103.1.

Palomeras, I., Carbonell, R., Ayarza, P., Martí, D., Brown, D., Simancas, J., 2011. Shear wave modeling and Poisson's ratio in the Variscan Belt of SW Iberia. Geochemistry Geophysics Geosystems 12. doi:10.1029/2011GC003577.

Palomeras, I., Carbonell, R., Flecha, I., Simancas, F., Ayarza, P., Matas, J., Martínez-Poyatos, D., Azor, A., González-Lodeiro, F., Pérez-Estaún, A., 2009. Nature of the lithosphere across the Variscan orogen of SW Iberia: Dense wide-angle seismic reflection data. Journal of Geophysical Research 114, 1-29. doi:10.1029/2007JB005050.

Pfiffner, O.A., Frei, W., Finckh, P., Valasek, P., 1988. Deep seismic reflection profiling in the Swiss Alps: Explosion seismology results for line NFP 20East. Geology 11, 987-900.

Poppeliers, C., Pavlis, G.L., 2003. Three-dimensional, prestack, plane wave migration of teleseismic P-to-S converted phases:1. Theory. Journal of Geophysical Research 108, 2112. doi:10.1029/2001JB000216.

Pratt, L., Costain, J.K., Glover, L., 1988. rocks Exposed / Buried Mesozoic Basins Positive Bouguer Gravity. Journal of Geophysical Research 93, 6649-6667.

Prodehl, C., Mooney, W., 2012. Exploring the Earth's Crust - History and Results of Controlled Source Seismology, in: The Geological Society of America Memoir, 208, p. 764.

Prossen, I., 1991. The Reflection Moho along the COCORP Northwest U.S. Transect, in: Continental Lithosphere: Deep Seismic Reflections, Geodynamics 22. volume Geodynamic, pp. 315-322.

Reich, H., 1957. In Suddeutschland seismisch Ermittelte tiefe Grenzflachen und ihre geologische Bedeutung. Geologische Rundschau , 1-17.

Reston, T.J., 1988. Evidence for Shear Zones in the Lower Crust offshore Britain. Tectonics 7, 929-945. 
Revenaugh, J., 1995. A scattered-wave image of subduction beneath the transverse ranges. Science (New York, N.Y.) 268, 1888-92. doi:10.1126/science.268.5219.1888.

Riahi, M.A., Lund, C., Pedersen, L.B., 1997. Three-dimensional image of the Moho undulations beneath the Gulf of Bothnia using wide-angle seismic data. Group 1993, 461-471.

Rondenay, S., 2009. Upper Mantle Imaging with Array Recordings of Converted and Scattered Teleseismic Waves. Surveys in Geophysics 30, 377405. doi:10.1007/s10712-009-9071-5.

Roure, F., Choukroune, P., Berastegui, X., Matheron, P., Bareyt, M., Seguret, M., Camara, P., Deramond, J., 1989. ECORS Deep Seismic Data and Balanced cross sectins: Geometric Constraints on the Evolution of the Pyrenees. Tectonics 8, 41-50.

Ryberg, T., Tittgemeyer, M., Wenzel, F., 2000. Finite difference modelling of P-wave scattering in the upper mantle. Geophysical Journal International 141, 787-800. doi:10.1046/j.1365-246x.2000.00117.x.

Ržek, B., Vavrycuk, V., Hrubcová, P., , Zedník, J., W.G., C., 2003. Crustal anisotropy in the Bohemian Massif, Czech Republic: Observations based on Central European Lithospheric Experiment Based on Refraction (CELEBRATION) 2000. Journal of Geophysical Research 108, 1-15. doi:10.1029/2002JB002242.

Salmon, M., Kennett, B., Stern, T., a.R.a. Aitken, 2012. The Moho in Australia and New Zealand. Tectonophysics doi:10.1016/j.tecto.2012.07.009.

Sheehan, A., Shearer, P.M., Gilbert, H., Dueker, K., 2000. Seismic migration processing of P-SV converted phases for mantle discontinuity structure beneath the Snake River Plain, western United States. Journal of Geophysical Research 105, 55-65.

Shragge, J., Bostock, M.G., Rondenay, S., 2001. Multiparameter twodimensional inversion of scattered teleseismic body waves 1 . Theory for oblique incidence. Earth 106, 30771-30782. doi:10.1029/2001JB000326.

Simancas, J., Carbonell, R., González-Lodeiro, F., Pérez Estaún, A., Juhlin, C., Ayarza, P., Kashubin, A., Azor, A., Martínez-Poyatos, D., 
Almodóvar, G., E., P., Saéz, R., Expósito, I., 2003. Crustal structure of the transpressional Variscan orogen of SW Iberia: SW Iberia deep seismic reflection profile (IBERSEIS). Tectonics 22. doi:10.1029/2002TC001479.

Snyder, D.B., Flack, A., 1990. Caledonian Age Reflectiors within the Mantle Lithosphere North and west of Scotland. Tectonics 9, 903-922.

Steer, D.N., Knapp, H., Brown, L.D.L., Echtler, H.P., Dennis, B., Berzin, R., 1998. Deep structure of the continental lithosphere in an unextended orogen: An explosive-source seismic reflection profile in the Urals (Urals Seismic Experiment and Integrated Studies). Tectonics 17, 143-157.

Steinhart, J., 1967. Mohorovičićic discontinuity, in: International Dictionary of Geophysics. Pergamon, Oxford 2, pp. 991-994.

Stephenson, R., 2004. EUROPROBE GeoRift, volume 3: intraplate tectonics and basin dynamicsthe lithosphere of the southern Eastern European craton and its margin. Tectonophysics 381, 1-4. doi:10.1016/j.tecto.2003.10.012.

Stratford, W., Thybo, H., 2011. Seismic structure and composition of the crust beneath the southern Scandes, Norway. Tectonophysics 502, 364382. doi:10.1016/j.tecto.2011.02.008.

Tesauro, M., Kaban, M.K., Cloetingh, S.a.P.L., 2008. EuCRUST-07: A new reference model for the European crust. Geophysical Research Letters 35, 3-7. doi:10.1029/2007GL032244.

Thompson, G., Catchings, R., Goodwin, D., Holbrook, S., Jarchow, C., 1988. Geophysics of the Western Basin and Range Province, in: Geophysical Framework of the Continental United States ed. L.C. Pakiser and W.D. Mooney, Boulder, Colo. Geologic SOc Ameriac Memoir, pp. 991-994.

Thybo, H., Nielsen, C.A., 2009. Magma-compensated crustal thinning in continental rift zones. Nature 457, 873-6. doi:10.1038/nature07688.

Thybo, H., Pharaoh, T., Guterch, A., 1999. Geophysical Investigations of the Trans-European-Suture-Zone, Tectonophysics, 314. volume 314. doi:10.1016/S0040-1951(99)00233-4. 
Thybo, H., Pharaoh, T., Guterch, A., 2002. Geophysical Investigations of the Trans-European-Suture-Zone II, Tectonophysics 360. volume 360.

Tittgemeyer, M., Wenzel, F., Fuchs, K., Ryberg, T., 1996. Wave propagation in a multiple-scattering upper mantle-observations and modelling. Geophysical Journal International 127, 492-502. doi:10.1111/j.1365246X.1996.tb04735.x.

Tittgemeyer, M., Wenzel, F., Fuchs, K., Ryberg, T., 1999. Scales of heterogeneities in the continental crust and upper mantle. Pure and Applied Geophysics 156, 29-52.

Valasek, P., Mueller, S., Frei, W., Holliger, K., 1991. Results of NFP 20 seismic reflection profiling along the Alpine section of the European Geotraverse (EGT). Geophysocal Journal International 105, 85-102.

Van der Velden, A., Cook, F., 2005. Relict subduction zones in Canada. Journal of Geophysical Research 110, 1-17. doi:10.1029/2004JB003333.

Van der Velden, A., Van Staal, C., Cook, F., 2004. Crustal structure, fossil subduction, and the tectonic evolution of the Newfoundland Appalachians: Evidence from a reprocessed seismic reflection survey. . Geological Society of Ammerica Bulletin 116, 14851498. doi:10.1130/B25518.1.

Vinnik, L., 1977. Detection of waves converted from P to SV in the mantle. Physics of the Earth and Planerary Interiors 15, 39-45.

Warner, M., Spaargaren, B., Jones, R., Watts, D., Doody, J., 1994. Highresolution images of the lower crust: deep seismic reflections from 15 to $180 \mathrm{~Hz}$. Tectonophysics 232, 225-237.

White, D., Forsyth, D., Asudeh, I., Carr, S., Wu, H., Easton, R., Mereu, R., 2000. A seismic-based cross-section of the Grenville Orogen in southern Ontario and western Quebec. Canadian Journal of Earth Sciences 37, 183-192. doi:10.1139/cjes-37-2-3-183.

White, D., Musacchio, G., Helmstaedt, H., Harrap, R., Thurston, P., Van der Velden, A., Hall, K., 2003. Images of a lower-crustal oceanic slab: Direct evidence for tectonic accretion in the Archean western Superior province. Geology 31, 997. doi:10.1130/G20014.1. 
Wilde-Piórko, M., Świeczak, M., Grad, M., Majdaski, M., 2010. Integrated seismic model of the crust and upper mantle of the TransEuropean Suture zone between the Precambrian craton and Phanerozoic terranes in Central Europe. Tectonophysics 481, 108-115. doi:10.1016/j.tecto.2009.05.002.

Wright, C., Goleby, B.R., Korsch, R.J., Barton, T., 1990. Deep seismic profiling in central Australia. Tectonophysics 173, 247-256.

Zandt, G., Ammon, C., 1995. Continental Crust Composition Constrained by Measurements of Crustal Poisson's Ratio. Nature 374, 152-154.

Zelt, B.C., Ellis, R.M., Clowes, R.M., Hole, J.A., 1996. Inversion of threedimensional wide-angle seismic data. Journal of Geophysical Research 101, 8503-8529.

Zelt, C.A., Sain, K., Naumenko, J.V., Sawyer, D.S., 2003. Assessment of crustal velocity models using seismic refraction and reflection tomography. Geophysical Journal International 153, 609-626.

Zelt, C.A., Smith, R.B., 1992. Seismic traveltime inversion for 2-D crustal velocity structure. Geophysical Journal International 108, 1634. doi:10.1111/j.1365-246X.1992.tb00836.x.

Zhu, L., Kanamori, H., 2000. Moho depth variation in southern California. Journal of Geophysical Research 105, 2969-2980. 
Figure 1: Figure illustrating Mohorovičićic (1910) interpretation. The top image shows the travel time vs distance plot for the October 8, 1909 Kulpa Valley earthquake and its aftershoks. Mohorovičić 's travel time picks of the different phases are displayed as the circles. The solid lines correspond to the $\mathrm{P}$ and $\mathrm{Pn}$ phases, travel time curves, differentiated by the scientist according to his model. The inset displays the approximate location of the Kulpa Earthquake The bottom shows the ray interpretation of the energy travelling from the source that resulted in two differentiated seismic arrivals what the scientist interpreted to be the P and Pn phases. (after Mohorovičićic (1910); Jarchow and Thompson (1989))

Figure 2: Shot gather shot number A3 (transect A) of the wide-angle seismic reflection data set of the INBERSEIS-WA project. For more details on the processing and interpretation of this data set see: Flecha et al. (2009); Palomeras et al. (2009, 2011). This shot gather is showed decimated at different trace spacing. This figure illustrates to some degree the evolution of the refraction data acquisition with an increase of the number of seismic recorders. From top to bottom the trace spacings are of $5 \mathrm{~km}, 2.5 \mathrm{~km}, 1 \mathrm{~km}$, and $400 \mathrm{~m}$. Not the increase on lateral resolution as the number of traces is increase. Note the Moho reflection identified as the $\mathrm{PmP}$ (with a red arrow) appears and the lateral continuity is increased when the trace spacing is reduced. The shot record has been reduced with a velocity of $8.0 \mathrm{~km} / \mathrm{s}$. This figure has been adapted from (Palomeras et al. 2009).

Figure 3: Filter panels of shot record B5 (transect B) of the wide-angle seismic reflection data set of the INBERSEIS-WA project. For more details on the processing and interpretation of this data set see: Flecha et al. (2009); Palomeras et al. (2009, 2011). From top to bottom the shot displayed after different band-pass filtering have been applied. From top to bottom the frequency band pass filters are: $0.25,2,6,8 \mathrm{~Hz} ; 6,8,12,15 \mathrm{~Hz} ; 10,12,18$, $20 \mathrm{~Hz}$; and 18, 20,30, $35 \mathrm{~Hz}$. This figure reveals the change in resolution due to the change in frequency content. Note that the PmP reflection at wide-angle $(90-120 \mathrm{~km})$ is visible already at low frequencies. The same structure the Moho at normal incidence requires higher frequencies note the increase in the energy of the normal incidence reflectivity of the Moho, mid- and lower-crust. This is most probably a result of the internal structure. The red arrow indicates the location of the base of the Moho discontinuity. This figure has been adapted from (Palomeras et al. 2009). 
Figure 4: Basic principles of Receiver function imaging: a) Illustrates the Energy partitioning of an incident P-wave at an interface (top) between two media with different physical properties (seismic P, S wave velocities and or density). Inverted black triangles denote seismic recording stations. An incident $\mathrm{P}$ wave generates a reflected $\mathrm{P}$ and a reflected $\mathrm{S}$, and a transmitted $\mathrm{P}$ and a transmitted $\mathrm{S}$ denoted $(\mathrm{Ps})$. This latter phase is $\mathrm{S}$ conversion of the incident $\mathrm{P}$ wave. The bottom panel illustrates a seismogram recorded by a surface station (represented by the inverted black triangles in the top figure). The direct $\mathrm{P}$ wave (the transmitted $\mathrm{P}$ ) corresponds to the highest amplitude arrival, while the converted Ps arrives within the coda. The time difference between the $\mathrm{P}$ and the Ps places constraints on the layer thickness. The comparison between the amplitude of the $\mathrm{P}$ and the Ps provides constraints on the impedance contrast of the interface (contrast between the physical properties that characterize both layers). b) Cartoon showing the shape of the recorded wave front of the converted phase due to the horizontal dimension of a heterogeneity (represented by a) as a function of the wavelength of the source signal $(\lambda$. In receiver function imaging the source signal is considered to be a plane wave. In the case $\lambda \ll a$ the converted (Ps) phase is also a plane wave, while in all other cases $\lambda \gg a$ the converted wave is a scaterred phase. This figure has been modified from Rondenay (2009).

Figure 5: Comparison of the seismic signature of the Moho between normal incidence and wide-angle seismic reflection data. At the bottom, the inset map mark by (a) shows the location of the IBERSIES-WA seismic reflection transect. The inset map labeled as (b) is the geological setting of the SW Iberia orogen, the study area, and design of the IBERSEIS deep seismic reflection experiment. The experiment consisted of a normal incidence transect and two wide angle profiles. The normal incidence seismic profile IBERSEIS is shown as a red line. The location of the wide.angle profiles are indicated as green dashed lines. The two profiles feature three and six shot points, respectively. The red circles indicate the shot positions. Blue circles indicate the position of magnetotelluric stations. Data details, processing, interpretation and implications of this images are discussed in Simancas et al. (2003); Palomeras et al. (2009). The time migrated IBERSEIS-NI normal incidence Vibroseis deep seismic reflection image (c), The transect is $260 \mathrm{~km}$ long. Note the change in character of the Moho discontinuity across the section, simple ans sharp in the south, and it increases in thickness towards the north, and in some cases it looses continuity. Details of the different wide-angle shot gathers is displayed from $\mathrm{d}$ to $\mathrm{h}$, corresponding to: $\mathrm{d}$ shot record A1; e,shot record A2; f,shot record A3; g,shot record B5; and h shot record B6; The red stars on diagram c indicated the projected locations (following the surface geology) of the source position. The double arrow segments beneath the normal incidence section (c) mark the approximate areas of the Moho mapped by the wide angle shot records. Note the change of character at normal incidence and wide-angle. Red arrows mark the base of the Moho in c. 
Figure 6: ALCUDIA deep seismic reflection profile with the surface geologic constraints. (top) Geological cross section along the seismic transect with key geological units. (Bottom) Time migration image of Alcudia deep seismic reflection profile In this figure the horizontal axis corresponds to CDP numbers and the vertical axis corresponds to two way travel time (TWTT). The inset map displays the location of the ALCUDIA transect within the Iberian peninsula. The dashed rectangle emphasizes the wedge feature with a relatively high amplitude event penetrating the upper mantle mentioned in the text. This image has been modified from Martínez Poyatos et al. (2012).

Figure 7: Compilation of multiseismic data which provided a series of complimentary views of the Moho beneath the Caledonides. PmP indicates the position of the $\mathrm{P}$ wave reflected energy from the Moho (red arrows). The refraction data places constraints on the depth position of the crustal interfaces and in particular the depth to the crust-mantle transition. Land and Marine (OBS) refraction/wide-angle seismic reflection data where acquired (Morgan et al. 2000). Processed CMP images of the DRUM and GRIDS-17. These transects are a couple of examples of the transects acquired within the BIRPS programme in the Caledonides. The seismic reflection normal incidence images imaged a clear Moho as a relatively thick, high amplitude and laterally continuous event which is the base of the crustal reflectivity at approximately 9-20 s TwT. Both images also reveal outstanding sub-crustal reflections (The Flannan reflector). A discussion on the mantle reflection events can be found in McBride et al. (1995). Receiver function images as a function of back-azimuth (Asencio et al. 2003) place constraint on the geometry of the Moho. The frequency content is two loo low to be able to provide any information on the internal structure and thickness of the Moho interface. The location of the Moho correlates with the reflected Moho in the CMP profiles, DRUM and GRID-17. The image is also consistent with the refraction/wide-angle seismic data Morgan et al. (2000). The receiver function were acquired for station located near the northern coast of Scotland (Stations ORE and RRR), their approximate locations are marked by a black diamond in the location map inset. The location of the CMP lines is also indicated in the map by black lines. The expanding spread profile was acquired using two ships one fired an airgun array as controlled source and the other towed a streamer. The former ship moved to the west and the latter to the east (Morgan et al. 2000) Further details on the acquisition and processing can be found in Morgan et al. (2000).

Figure 8: Deep seismic reflection transect across the Sourthern Urals (unmigrated section), the URALS-95 transect (Berzin et al. 1996; Steer et al. 1998). The red arrows mark the base of the Moho discontinuity. The inset map illustrates the location of the transect in the southern Urals. The map is a topographic map. The geological terranes are indicated at the top of the seismic cross-section (Adapted from (Steer et al. 1998)). 
Figure 9: Wide-angle CMP stacked of the explosive shot record acquired within the URSEIS-95 Details in the processing and its implication in Carbonell et al. (1998). The inset topographic map indicates the location of the transect. The top panel shows the wide-angle stack with the interpreted location of the Moho using the high amplitude reflection as picking criteria. The middle panel is the depth converted section, The botton pannel is the URSEIS-95 stacked section 8 of the explosive data (from Steer et al. (1998)) with the wide-angle Moho picked superimposed on it to illustrated the position of the Moho beneath the Magnitogorsk arc (Image adapted from (Carbonell et al. 1998)).

Figure 10: Multi-seismic data that characterizes the TESZ in northern Europe. The CMP lines in ( $\mathrm{a}, \mathrm{b}$ and $\mathrm{c}$ ) correspond to Line $\mathrm{A}$ and $\mathrm{B}$ part of the BABEL project. The CMP images also show the refraction velocity model, these have been extracted from BABEL Working Group (1993b). The location of the CMP lines are indicated in the inset map (e). (d) Is the RF south-north time section TOR profile indicated by a dotted green line in the Map. Details in the processing which can be found in the original publication of this data (Alinaghi et al. 2003) include: stacking in $50 \mathrm{~km}$ wide windows with $10 \mathrm{~km}$ moving intervals high pass filter above $0.2 \mathrm{~Hz}$ was applied to eliminate low frequency noise. Note the increase of Moho depth which partly overlaps with the refraction velocity model in (b red arrow) when projected offshore. Note also that this increase is not mapped either by the refraction velocity model nor by the CMP images. Also notice the lack of reflectivity at proposed Moho depth along the first part of the CMP in (b). (e) The location map has been modified from Alinaghi et al. (2003). The map also includes de distribution of seismic station for passive recording of of TOR, SVEKALAPKO, GRSN and GEOFON. CF and TESZ indicate the Caledonian Front and the Trans-European Suture Zone (TESZ) respectively.APSL indicates the line of suture between Proterozoic and Archaean provinces in Finland. The Broad-Band and short period stations are indicated by triangles and circles, respectively. The stations of the GRSN are indicated by white triangles represent The triangles delimited by polygons represent GEOFON stations. The dotted straight lines offshore represent the acquisition geometry of the 2D lines acquired within the BABEL project. The green dotted line beneath ( $\mathrm{a}, \mathrm{b}$, and $\mathrm{c}$ ) CMP images indicates the offshore projection of the RF image. 
Figure 11: Multi-seismic data acquired to characterize the Precambrian terranes of northwestern Europe. The top figures labeled $\mathrm{a}$ and $\mathrm{b}$ correspond to the Babel CMP lines 1 and 3,4 . The velocity models constrained by wide-angle data are overlayed. The 9velocities were estimated by ray tracing. Detailed explanations of the models and seismic section can be found in the original publication (BABEL Working Group 1993a). The location of the CMP lines are indicated in the inset map c. The map also includes de distribution of seismic station for passive recording of of TOR, SVEKALAPKO, GRSN and GEOFON. CF and TESZ indicate the Caledonian Front and the Trans-European Suture Zone (TESZ) respectively.APSL indicates the line of suture between Proterozoic and Archaean provinces in Finland. The Broad-Band and short period stations are indicated by triangles and circles, respectively. The stations of the GRSN are indicated by white triangles represent The triangles delimited by polygons represent GEOFON stations. The dotted straight lines offshore represent the acquisition geometry of the 2D lines acquired within the BABEL project. The location of the lines represented in a and $\mathrm{b}$ are indicated by arrows. The green doted line indicated the approximate location of the RF transect illustrated in d. This correspond to a south-north oriented RF time section across the SVEKALAPKO network deployment from Alinaghi et al. (2003). RF were high passed $(0.2 \mathrm{~Hz})$ eliminating the low frequency noise. have been stacked from south to north in $50 \mathrm{~km}$ wide windows with a moving intervals of $10 \mathrm{~km}$. Note the sharp depth increase of the Moho $(\approx 20 \mathrm{~km})$. This increase in depth when projected east offshore would, approximately, correlate the depth increase (marked by the red arrow in a) of the Moho constrained by the refraction data. Similarly the thinning to the north would correlate to the thinning indicated by the seismic velocity model and the CMP image (in b). The RF stack has been extracted from (Alinaghi et al. 2003).

Figure 12: Transect across the Precambiran terranes of Western Canada. The top map (a) is the Geological map of northwestern Canada shows the locations of the Normal incidence and the co-located wide-angle seismic reflection datasets acquired within the LITHOPROBE project SNORCLE. The colours indicate the different geologic terranes which are specified in the legend. The Normal incidence profile 1 is displayed in (b), with the Moho event denoted with the red arrow-heads. The seismic image is extracted from Cook et al. (1998). (c) Displays the velocity model derived from the co-located wide-angle seismic reflection data (from Clowes et al. (2005)). A detail presentation and discussion of these unprecedented dataset can be found in Cook et al. (2004); Clowes et al. (2005).

Figure 13: Deep normal incidence deep seismic reflection transect across the Pyrenees. a) Map of the Iberian Peninsula, the dash lines 12 and 3 corresponds to the Receiver Function Images in (b) labeled 1, 3 and, 3. The straight continuous bold line in the Map that crosses the Pyrenees indicates the location of the ECORS CMP transect. c) The line drawing of the ECORS-Pyrenees transect. The red arrows mark $t$ base of the Moho discontinuity. Note the change in character from south to north. The lateral continuity of the deep reflectivity varies along the transect being longer in the south than in the north. Note also the Moho step and the lack of a proper Moho reflection beneath the axial zone of the Mountain orogen. Adapted from (Choukroune and Team 1989). 
Figure 14: Combined imaged of results from the TRANSALP research programme. (a) The inset topographic map indicates de location of the TRANSAP transect across the Alps. (b) The CMP deep seismic cross-section acquired using Vibroseis sources after stack and depth migration. Details on the acquisition and processing cab be found in Lüschen et al. (2004) Within the TRANSALP, a dynamite profile was also acquired, coincident with the Vibroseis. (c) Is the dynamite stack and time-migrated seismic image section Lüschen et al. (2004). All sections are shown at the same scale without any vertical exaggeration. Images addapted from Lüschen et al. (2004). (d) Crossection result from depth migrating short-period receiver functions along the TRANSALP profile (Figure extracted from Kummerow et al. (2004) The interpreted features are labeled: EM=European Moho, $\mathrm{AM}=$ Adriatic Moho, $\mathrm{I}=$ base of Mesozoic sediments and/or flysch sediments or Helvetic detachment, II = Sub-Tauern Ramp reaching the surface at the Inn Valley, III = SubDolomites Ramp reaching the surface at the tip of the Valsugana thrust belt, ACI $=$ Adriatic Crust Interface, a Adriatic mid-crustal feature Green and blue circles are Moho depths constrained from Pms times and transformed using velocities of 6.0 and $6.3 \mathrm{~km} / \mathrm{s}$, respectively. Further details can be found in the original publication of the data and interpretation by Kummerow et al. (2004). The superposition of receiver functions and seismic reflection line drawings is displayed in (e) (also extracted from Kummerow et al. (2004). 
Figure 15: Multiseismic constraints on the Moho discontinuity beneath the Himalaya and Tibet collision zone. These are three examples of seismic controlled and passive source data which reveal the geometry of the Moho beneath the Himalaya. (a) is the map of the study are on which there are marked the different acquisition experiments, The seismic images displayed here include the INDEPTH normal incidence (b) extracted from (Alsdorf et al. 1998). This is a combined Multichannel CMP deep seismic reflection and wide-angle shot recorrds across the Himalayas INDEPTH research project. It is time migrated and depth converted The stack is a combination of a series of normal incidence CMP profiles and wide-angle seismic reflection data, approximately oriented North-South (projected) Further details on the processing of this data set can be found in Alsdorf et al. (1998). The receiver function imaged resulting of the HiCLIMB experiment is also displayed this image has been modified from (Nábelek et al. 2009). The image includes at the top a simplified diagram of the topography, and the depth of the interpreted Moho discontinuity. The horizontal black line labeled INDEPTH is the projected overlap of the CMP line. The Moho of the Indian plate is located at approximately $40 \mathrm{~km}$ depth (it is thin beneath the India and it thickens and increases in depth towards the north. Between $29^{\circ}$ and $30^{\circ}$ Latitude at a depth of $60-70 \mathrm{~km}$ there is a $200 \mathrm{~km}$ long lens revealing a double Moho. Towards the north the Moho weakens, and it even disappears (at a latitude of $32^{0}$ ), at $33^{0}$ the Moho is visible again as an approximately $10 \mathrm{~km}$ thick structure. Beneath the stack the image of the Moho illuminated from the North and from the south respectively. Further details on the data, processing and interpretation can be found in Nábelek et al. (2009). (c) Corresponds to the cross section obtained by using the broad-band deployments of subsequent INDEPTH data acquisition experiments (Kind and Yuan 2010). The location of the image is marked in (a). The top shows the Receiver function migrated image using the Pms phases. The two cross section bellow show the migration of the multiples (PpPms and PpSms), respectively. The depth of the Moho as determined from the converted phases and multiples is also show at the base. This image has been extracted from (Kind and Yuan 2010). The overlap with the CMP INDEPTH line is also marked by the horizontal bold line labeled INDEPTH. The projected overlap (Following the Geology) between the HiCLIMB and the East-Line is indicated by the location of the two suture zones. Note that a double moho, is also observed in this image at approximately the same location. Further details on the interpretation of this image can be found in (Kind and Yuan 2010). 